Review

\title{
Assessment of the production of biodiesel from urban wastewater-derived lipids
}

\author{
Zuzana Frkova Dr. ${ }^{\mathrm{a}, *}$, Silvia Venditti ${ }^{\mathrm{a}}$, Patrick Herr ${ }^{\mathrm{b}}$, Joachim Hansen ${ }^{\mathrm{a}}$ \\ ${ }^{a}$ University of Luxembourg, Faculty of Science, Technology and Communication, 6, rue Richard Coudenhove-Kalergi, L-1359, Luxembourg, Luxembourg \\ ${ }^{\mathrm{b}}$ REMONDIS Aqua Industrie, Brunnenstrasse 138, D-44536, Lünen, Germany
}

\section{A R T I C L E I N F O}

\section{Keywords:}

Wastewater derived lipids

Biodiesel

Wastewater valorization

FOG

Circular economy

\begin{abstract}
A B S T R A C T
Production of biodiesel is one of the most important European targets within renewables for the future. To consider biodiesel a feasible alternative to fossil fuel, unconventional resources need to be exploited. This review aims to provide up-to-date knowledge on the existing reuse of lipids from urban wastewater to produce biodiesel. Lipids are readily removed by mixed microbial populations during wastewater treatments in sewage plants. Assessment results on potential annual European market supply indicate 3-414 $10^{4}$ tons (min for activated and max for grease trap sludge) of potentially extractable biodiesel from wastewater and an expected biodiesel demand of $14.810^{6}$ tons. Considering the prospect of transforming sewage plants into biorefineries, we may cover on average $1.5,6.2,6.7$ and $24.4 \%$ of activated, primary, scum and grease trap sludge respectively, of the European biodiesel market from wastewater-derived lipids. In addition, by implementing an optimized biotechnology selector, the overall biodiesel yield could be higher due to increased lipid incorporation into microbial biomass. This is not an insignificant amount and, if efficiently implemented, could represent an exploitable resource for biofuel production, an important and desired step towards a circular economy. The technology readiness level is still very low. There are several challenges and possible drawbacks, e.g., biogas yield loss, substrate depletion, or formation of floating sludge. Finally, no definitive legislative barriers towards wastewater-derived lipids have been identified; however, quality criteria as well as waste status have to be defined.
\end{abstract}

\section{Introduction}

As human populations and demand for natural resources increase there is a growing need for more efficient reuse of raw materials. The circular economy initiative, supported by OECD (OECD, 2019), is regularly a priority topic at the World Economic Forum in Davos (Switzerland), and was adopted by the European Commission in 2015 (EC, 2015) to facilitate a smooth transition towards sustainable resources management. It aims to stimulate shifts from the "take-makedispose" (widely-cited expression to describe transformation of raw materials into products, which are then used until they are finally discharged as waste) behavior of a classical linear economy to a circular system where products and thereby materials are reused in new cycles. It proposes changing business models and product design as well as collaboration between suppliers and customers while creating economic value (i.e., new job opportunities, skills development in craft, design and material recovery). For this to happen, changes in people's perspective and attitude are essential (Kehrein et al., 2020). A common
EU target is to recycle 65\% of urban waste by 2035 (EC, 1999; $\mathrm{EU}, 2008)$. An economic incentive for producers is to put more green products on the market while supporting recovery and recycling schemes (e.g., for vehicles). Production of fatty acid methyl esters (FAMEs), namely biodiesel, remains one of the most important European targets for the future in terms of renewable fuel for transportation (Ajanovic, 2013). In fact, the value of $10 \%$ of fuel to be renewable, set by the European Parliament, still remains the final objective to be achieved by 2020. In addition, the revised Renewable Energy Directive (RED II) (EU, 2018) submitted that member states must require fuel suppliers to deliver at least $14 \%$ of the energy consumed by road and rail transport from renewable sources. The share of biodiesel produced from waste-based feedstock is expected to grow substantially by 2030 . Recently, many reports and regulations have been introducing circular economy principles in areas where sustainability of renewables is strongly considered. Generally, renewable sources having a high environmental impact such as indirect land use change due to crop-to-fuel cultivation, which needs to be better regulated. Accordingly, the limit

\footnotetext{
* Corresponding author.

E-mail address: zuzana.frkova@uni.lu (Z. Frkova).
} 
for "first generation" biodiesel (derived from vegetable oil and animal fat) will be fixed at 7\%, making the use of alternative resources, such as used cooking oil, wastewater from agro-industries (slaughterhouses, fish-processing factories) and urban wastewater rich in lipids (fat, oil, grease; FOG) more favorable and attractive for the European market (EC, 2009). FOG originates from household discharge (i.e., vegetable oils, meat and dairy products), therefore, municipal wastewater contains remarkable quantities of it. When entering the sewage disposal system, FOG causes several problems, both in the drainage system, and in wastewater treatment plants themselves.

This review article gives an overview of the fate of lipids in sewage systems, diurnal lipid concentrations and composition in the influent, and the current state of lipid reuse from urban WWTPs. We emphasize the potential for harvesting lipids at different stages of wastewater treatment, and map lipid profile variations. In addition we describe methods and technologies (more or less developed) for utilizing sludge to produce biodiesel, although lipid upcycling methods are scarce, and to date none of them have been deployed full scale. We further investigate the market potential (supply-, and demand-side) as well as readiness, risks and legal framework for biodiesel produced from wastewater derived lipids.

\section{Methodological approach}

\subsection{Search strategies}

Data were extracted from Web of Science (Clarivate Analytics, PA, USA), Eurostat, EU Commission, OECD databases and individual member states reports concerning circular economy (Luxembourg - 3 documents, Germany - 2, United Kingdom - 2, Ireland - 1). Besides 25 governmental documents and 10 project webpages, a query of various combinations of keywords in the scientific database (such as "biodiesel urban/municipal wastewater", "biodiesel urban/municipal wastewater sludge", "biodiesel extraction urban/municipal wastewater", "biodiesel oleaginous microorganism* urban/municipal wastewater", "oleaginous bacteria biodiesel", "lipids urban/municipal wastewater treatment process", "supercritical extraction lipid sludge", "supercritical extraction biodiesel wastewater", "hydraulic pressure lipid sludge", "DIC lipid sludge/wastewater", "microwave extraction lipid sludge/wastewater", "ultrasound extraction lipid sludge/wastewater") generated 275, 74, $52,3,80,103,13,18,5,1,13,17$ peer reviewed articles, respectively, refined by document type (letters excluded -2 documents) and language (Spanish -4 documents excluded, Chinese -1 and Portuguese 1). It is important to note, that by using this particular database and selection, we might have missed relevant documents which were not peer reviewed or were written in languages other than English. Each selected collection was added to the Marked List (function in Web of Science), with a total of 449 records after the removal of duplicates. The records were exported as a plain text and thereafter processed using comprehensive science mapping analysis ( $\mathrm{R}$ package Bibliometrix (Aria and Cuccurullo, 2017)). All publications span a period between 1994 and 2020, with a scientific production peak covering the last decade which demonstrates the significant interest raised in the scientific community. Source dynamics are depicted in Fig. 1 . The most relevant sources are Bioresource Technology (68 articles), Algal Research (24), Water Science and Technology (13), and Water Research (10) journals. Except for Water Science and Technology, increasing impact factor correlates with the annual increase in number of articles published in the respective journals. The most cited sources are Bioresource Technology and Water Research, almost 3000 and 700 citations each. 53 corresponding authors' countries worldwide were identified, most of the articles originated in the USA (79) and China (70), with very low international collaboration (Multiple Countries Publication ratios of 0.1 and 0.3 , respectively, higher ratio, indicates increased collaboration). The number of studies included in qualitative synthesis was 171, from which 45 were used for the quantitative synthesis.

\subsection{Selection criteria}

To the best of our knowledge we used all the available results and data from all articles accessible via our databases. For oleaginous microorganisms and extraction/transesterification protocols, we excluded those with the lower/lowest lipid/biodiesel yield per dry biomass or lower/lowest lipid production if a studied article reported more than one organism or method. Data were taken directly from the articles, in some cases, biodiesel yield was calculated from the given percentage of lipid yield. It is important to highlight the scarcity of literature presenting both the biodiesel yield (extracted FAMEs/dry sludge weight*100) and its fatty acid composition. The maximum yield at different stages of wastewater treatment were compared and One-way Analysis of Variance (ANOVA) was computed in R.

\subsection{Terminology}

The terminology needed to be unified to the most frequently used term. For example: i) "solvent extractables" (Hall et al., 2011) includes triacylglycerols, phospholipids and other nonsaponifiable lipids such as cholesterols equal "lipid content"; ii) in order to quantify the amount that can be converted to biodiesel, these lipids are transesterified to FAMEs, therefore "transesterifiable lipids" (Cea et al., 2015) or "neutral lipids" (Cea et al., 2015) are equal to "FAMEs" or simple "biodiesel" (Olkiewicz et al., 2012).

\section{Lipids in urban wastewater treatment plants and their conversion to biodiesel}

\subsection{Incidence and utilization of FOG in urban wastewater systems}

Lipids (fat, oil, grease; FOG) often present an issue already when wastewater is being collected and transported, and thereafter when being treated in wastewater treatment plants (WWTPs) (Williams et al., 2012). Applying British statistics (SevernTrent, 2016) at a larger scale, the annual costs related to cleaning of sewers and removal of blockages caused by FOG were calculated to 1 EUR per PE (population equivalent). This means that over 500 mil EUR per year are necessary for maintenance of pipelines in the whole EU. Estimating the follow-up costs for the remaining FOG being treated in WWTPs is more difficult. Lipids have a detrimental effect on oxygen transfer to microorganisms, resulting in a decline of microbial activity in activated (secondary) sludge (Henkel, 2010). Additionally, adsorption of lipids to biomass decreases the ability of sludge to settle resulting in bulking and/or foaming (Andreasen and Nielsen, 2000; Soddell et al., 1998). FOG can easily be separated at the inlet by mixing with cellulosic wastes, paper, pieces of wood and other light materials, using a screen and a grease trap. However, not all WWTPs are equipped with grease traps ("oilwater separators"), since this upper layer is considered to be hazardous material according to the European Waste Classification (EWC:13-05-08 (EPA, 2015)) and needs to be properly treated and disposed of at high cost. The current recovery and reuse of wastewaterderived lipids (FOG), is limited to biogas production in digesters. The majority of the lipid potential in sewage is currently not utilized. Instead it is dissolved and gets partially degraded to $\mathrm{CO}_{2}$ or is disposed of with sludge (incineration, composting, deposition in landfill, use in the production of construction material), which incurs additional costs for WWTPs, accounting for up to $65 \%$ of the total plant operational costs (Zhao and Kugel, 1996). Assuming that activated sludge has a growth yield efficiency of $0.5-1 \mathrm{mg}$ dry weight per $\mathrm{mg}$ of biological oxygen demand (BOD), $1 \mathrm{~kg}$ of removed BOD will generate $0.5-1 \mathrm{~kg}$ of dry excess sludge depending on the sludge age (DWA, 2016; Liu, 2003). Efficient valorization of this waste, e.g., turning it into biodiesel (fatty acid methyl esters; FAMEs) would eliminate the costs conferred in its disposal, and in addition, would generate a net profit.

Mean concentration of long chain fatty acids (LCFAs) in urban 


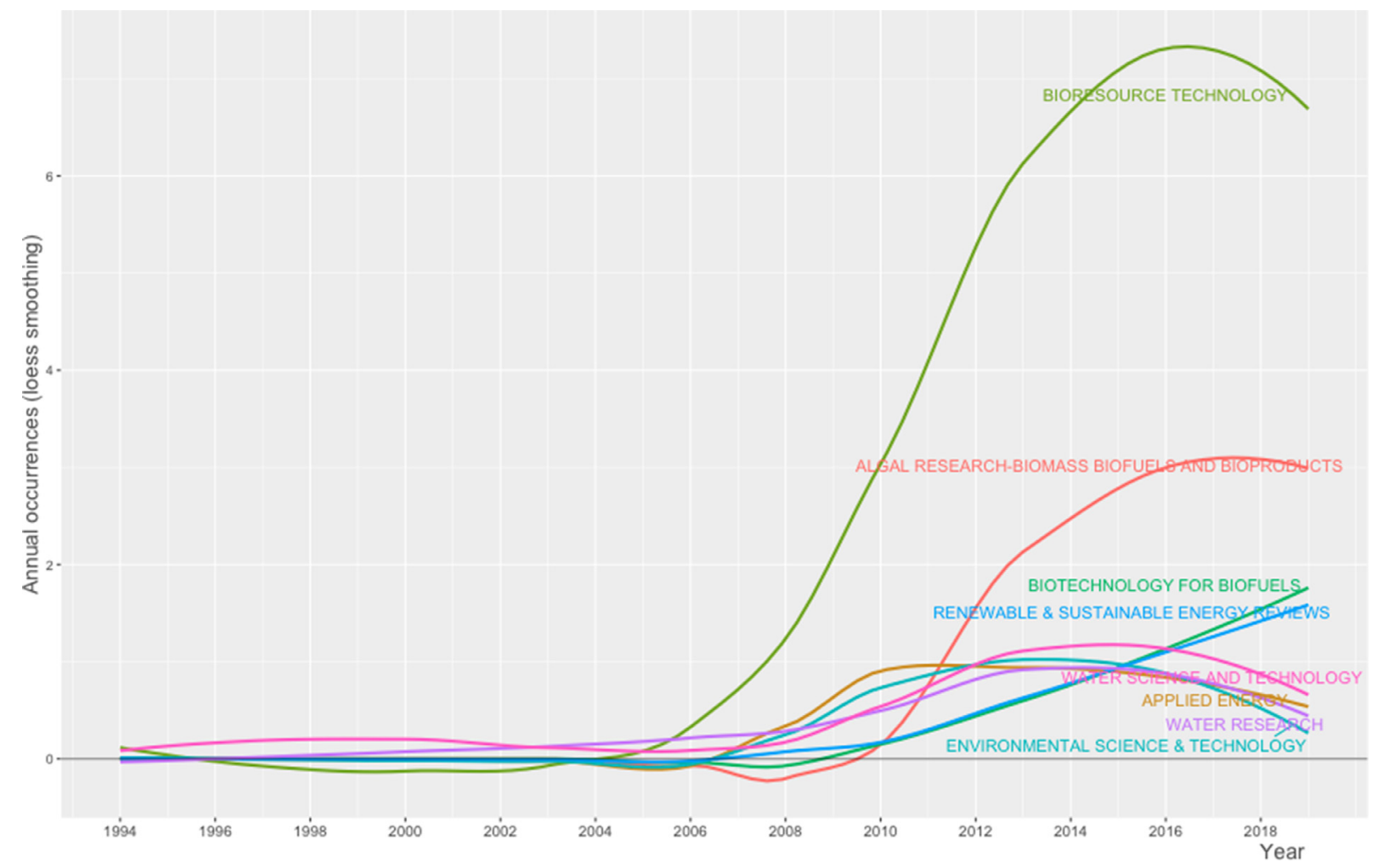

Fig. 1. Number of scientific publications per year in corresponding journals.

wastewater influent has a wide range. The lowest range reported is from 19 to $32 \mathrm{mg} \mathrm{L}^{-1}$ (Dignac et al., 2000; Quéméneur and Marty, 1994), medium from 98 to $131 \mathrm{mg} \mathrm{L}^{-1}$ for 3 Romanian WWTPs (Beldean-Galea et al., 2013), and highest from 22 to $539 \mathrm{mg} \mathrm{L}^{-1}$ for diverse French WWTPs (Jardé et al., 2005). Quéméneur and Marty (1994) showed that $45 \%$ of the lipid fraction comes from feces and 55\% from kitchen waste. Kitchen wastewater contains 14-36\% lipids (Penn et al., 2018), derived from vegetable oils and animal fats. Vegetable oils are rich in 16:0 (palmitic acid), 18:1(n-9) (oleic acid), 18:2(n-6) (linoleic acid) and in B-sitosterol, while animal fats contain large amounts of 16:0, 18:0, 18:1(n-9) and cholesterol (Gunstone, 1967; Segura, 1988). Feces contain 4-23\% lipids (Mahlie, 1940) and their fatty acid fraction is dominated by three acids: 18:1(n-9), 18:0 and 16:0 (Williams et al., 1960).

The majority of FOG, $80-95 \%$, is in particulate form (size $>0.45$ $\mu \mathrm{m}$ ) (Dignac et al., 2000; Quéméneur and Marty, 1994). The major reported particulate fatty acids are 18:1(n-9), 16:0, 18:0 and 18:2(n-6). The dissolved fraction had a similar composition to the particulate, with a slight increase in 18:1(n-9) and 18:2(n-6) (Fig. 2). The fate of lipids during the wastewater treatment processes is not entirely understood (Chipasa and Medrzycka, 2008). Generally, it is agreed that the lipid removal mechanism from wastewater involves adsorption/desorption on particulate matter (Dueholm et al., 2001; Hwu et al., 1998), hydrolysis by extracellular enzymes and consumption of fatty acids by activated sludge bacteria (Hwu et al., 1998); resulting in small (Dignac et al., 2000) to significant changes in the composition of fatty acids (Beldean-Galea et al., 2013). Reports on removal efficiency for fatty acids are not consistent. Dignac et al. (2000) showed $98-100 \%$ overall removal in the activated sludge step, with 20:4n being degraded the least. Beldean-Galea et al. (2013) observed highest efficiency $(83.3 \%)$ in a WWTP comprising a combination of all treatment processes (physical, chemical and biological), while the lowest efficiency $(28.1 \%)$ in a WWTP was based on physical operation only. In another study, between 9 and $97 \%$ of dissolved fatty acids and $69 \%$ and $90 \%$ of particulate fatty acids were removed in a plant consisting of either physical-chemical or biological process units (Quéméneur and Marty, 1994).

Lipids are less responsive to biodegradation than other organic substances such as sugars and amino acids (Chipasa and Mesdrzycka, 2006). However, overall in the literature lipids are considered to be readily removed (even at high loads), especially in activated sludge. The results showed that in a WWTP containing activated sludge, the percentage of some unsaturated fatty acids (C20:2n6, C18:2n6c\&t, C18:1n9c\&t and C16:1n7) decreases during biological treatment, while the percentage of some saturated fatty acids (C22, C18, C16, C14 and C12) increases (Beldean-Galea et al., 2013). Another bioconversion in activated sludge suggested the production of LCFAs (long chain fatty acids) shorter by two carbon atoms as a result of the $\beta$ oxidation process (Chipasa and Medrzycka, 2008). Loehr and Roth (1968) showed that biodegradability of lipids $>C_{12}$ (LCFAs) in wastewater increases with decreasing carbon chain length and increasing degree of unsaturation. In addition, lower substrate utilization rates of LCFAs are expected because they are found in treated wastewater effluents, usually $>0.3 \mathrm{~g} / \mathrm{L}$ (Chipasa and Medrzycka, 2008).

\subsection{Biodiesel, composition and characteristics}

Industrially today, biodiesel (fatty acid methyl esters; FAMEs) is produced by processing vegetable oil or animal fat. These feedstocks are expensive and to some extent part of the ongoing food vs. fuel discussion.

Transesterification (Ma and Hanna, 1999) is the preferred method to process biodiesel from diverse feedstocks. Other methods include, direct use and blending of raw oils (Adams et al., 1983; Engler et al., 1983; Peterson et al., 1983; Strayer et al., 1983), micro-emulsions (Schwab et al., 1987) and thermal cracking or pyrolysis (Chang and Wan, 1947; Crossley et al., 1962; Niehaus et al., 2013; Pioch et al., 1993; Weisz et al., 1979).

Including transesterification, there are three different process routes by which sewage sludge can become a suitable substitute fuel in diesel 


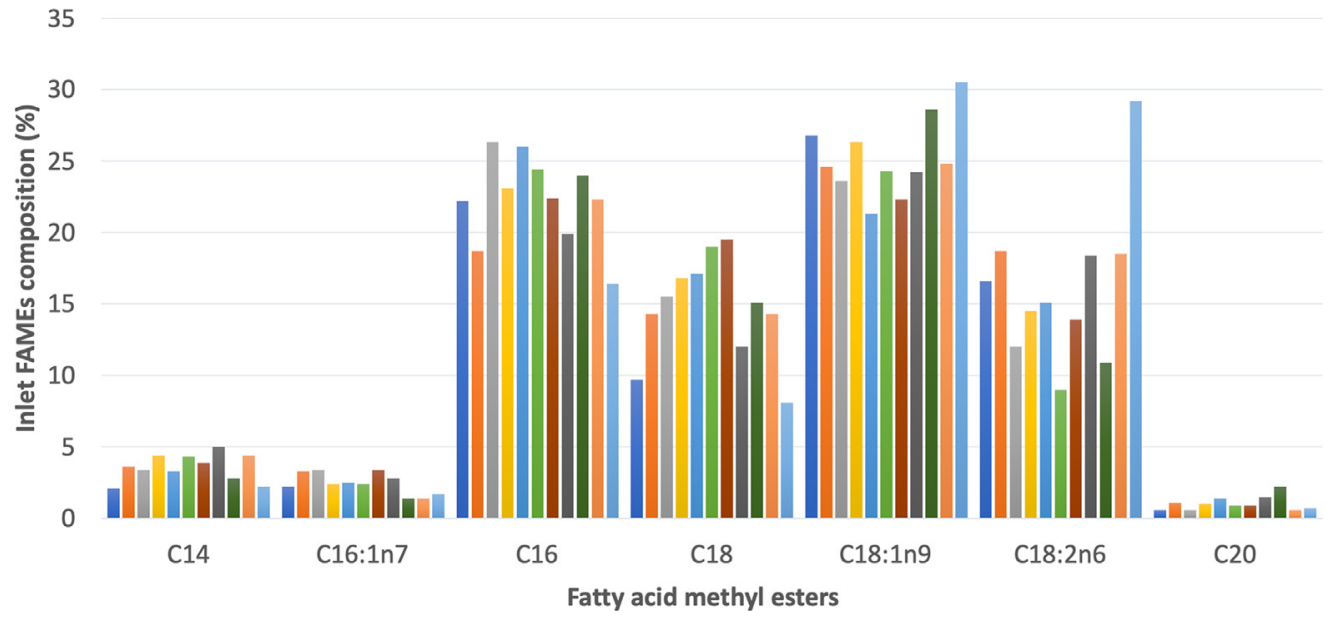

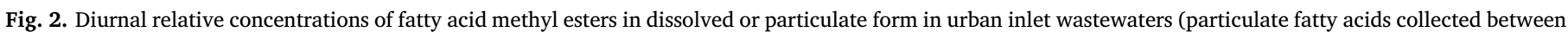
4 - 10am, $11 \mathrm{am}-4 \mathrm{pm}$, and dissolved between 4 - 10am depicted in column 1. -6., 7. - 9. and 10. - 11., respectively).

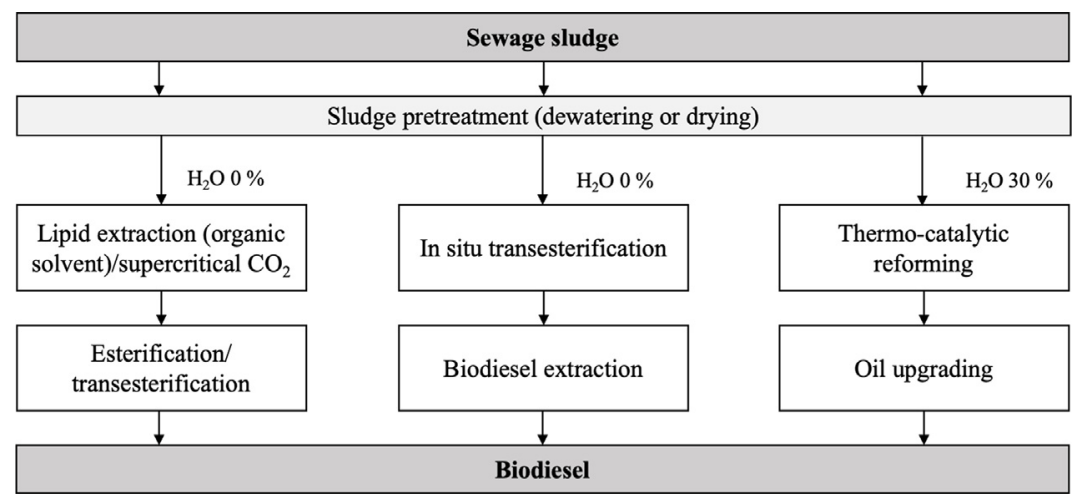

Fig. 3. Diagram of process routes for biodiesel production from sewage sludge.

engines (Fig. 3). The first necessary step for all possible routes is sludge dewatering. Since water may hinder the process, the water content of the sludge has to be reduced by suitable means prior to processing. Here, a combination of mechanical dewatering and thermal drying techniques can be applied. Technical implications of the dewatering step are related to the sludge management of wastewater treatment plant operators and to the fact that common practice measures are often disruptive. Vacuum drying, at $60{ }^{\circ} \mathrm{C}, 100 \mathrm{mbar}$, is preferred (this value was obtained from on-site data) to reach approximately $20-30 \%$ solid matter. No regular curve of water evaporation can be identified to recommend an optimal drying time as the evaporation of water is influenced by the type of vacuum dryer, the operating conditions (i.e., air temperature and vacuum rate) and the quality of the raw material. Technological know how is not yet advanced enough to recommend a unique solution, therefore, a hybrid method is often preferred to reduce the generally long drying time of a conventional vacuum dryer. After the dewatering step, several following routes are possible, described below.

A two-step biodiesel production route comprised of lipid extraction from the sewage sludge using organic solvents (such as n-hexane) or supercritical $\mathrm{CO}_{2}$. Subsequently the solvent is removed from the extracted lipid fraction by suitable measures (e.g. distillation), and the lipids are converted into biodiesel by direct esterification or transesterification of triglycerides and free fatty acids (Samios et al., 2009). According to the character of the feedstock, in most cases alkaline- or acid-catalyzed reaction routes are applied. The alkali reaction (catalyzed by $\mathrm{NaOH}, \mathrm{KOH}$, carbonates or corresponding sodium and potassium alkoxides) requires a low operating temperature achieving high conversion within couple of hours, it is the most commonly used method commercially. For the alkali-catalyzed transesterification, the glycerides and alcohol must be substantially anhydrous and low in free fatty acids (FFA) (Wright et al., 1944). If they are not, the alkali catalyst will react with FFA to form soaps, and additional water can cause hydrolyses of triacylglycerols releasing further FFA to form more soaps. The saponification reaction has been shown to lower the yield of biodiesel and to inhibit the separation of esters from glycerol (Van Gerpen, 2005). If water and FFA content exceeds 0.3 and $0.5 \%$, respectively (Berrios et al., 2007; Wright et al., 1944), acid-catalyzed (sulfuric, sulfonic, phosphoric, hydrochloric acids (ISTC, 2006) or aluminum chloride hexahydrate salt (Pastore et al., 2014)) transesterification takes place. The downside of the acidic approach are lower reaction rates (Siddiquee and Rohani, 2011; Van Gerpen, 2005).

In situ transesterification refers to lipid extraction and biodiesel conversion in a single process step. The solvent for lipid extraction and the catalyst for transesterification are added simultaneously to the sludge and after successful formation of biodiesel, FAME is removed by suitable measures (e.g. solid-liquid separation followed by phase separation).

In contrast to the previous processes, thermo-catalytic reforming can accept sewage sludge with a water content of up to $30 \%$ while other routes need completely dry sludge matter. During this process route, three substances are produced: hydrogen rich syngas, bio-oil and biochar. Biofuel can be produced from the liquid fraction. Because the oil is not suitable for direct use as fuel in a conventional combustion engine, it has to be upgraded by additional treatment. Hence a catalyzed hydrogenation treatment is applied, which removes heterogeneous atoms such as sulfur, nitrogen and oxygen or substitutes them with hydrogen. The resulting product complies with European fuel standards and 
therefore can be used as diesel (Schmitt et al., 2019).

For the most commonly used process route, esterification/transesterification, yield of lipids may vary according to the chosen method of lipid extraction. The extracted lipid content depends on the solubility of the fatty acids, and on the ability of a solvent to permeate biomass in releasing the lipid content (Menegazzo and Fonseca, 2019). Generally, different amount of lipids can be extracted from different treatment steps of WWTPs (Cea et al., 2015) (as described in detail in chapter 4.1). Additionally, sample/sludge pre-treatment was shown to have a substantial effect on potential lipid and FAMEs yield. For example, Wang et al. (2016) reported on a combination of three solvents (methanol, hexane and acetone) in different ratios added to sludge and different ratios of the solvents. Among the different variants, the solvent with the highest percentage of hexane (20:60:20) generated the largest lipid amount from scum sludge. The largest lipid amount in primary and activated sludge was yielded with the highest methanol portion (80:20:0). Activated sludge is mainly composed of microorganisms whose cell membranes contain phospholipids (polar head and unipolar tail), hence increasing the methanol concentration in the extraction mixture may disrupt cell walls, releasing more extractable materials than other solvents can (Dufreche et al., 2007). For FAME yield from scum sludge, the yield gradually increased with methanol percentage, the opposite was observed for primary and activated sludge. The fatty acid profiles were similar regardless of solvent ratio used (Wang et al., 2016). Similarly Revellame et al. (2010) observed the effect of methanol on sludge ratio and sulfuric acid concentration giving a maximum biodiesel yield of $4.88 \%$ from activated sludge (dry weight) at methanol to sludge ratio 25:1 (volume/weight) and sulfuric acid concentration of 4\% (volume/volume). Mondala et al. (2009) observed different FAME yields at different combinations of reaction temperature, sulfuric acid concentration and mass ratio of methanol to sludge. The highest yield from primary and activated sludge was observed at the highest sulfuric acid (5\%) concentration, and highest methanol to sludge ratio, $12: 1$ both at 50 or $75^{\circ} \mathrm{C}$. In contrast, Chi et al. (2018) did not observe a significant difference in FAME yield when pre-treated with ultrasound. The heat and free radicals released during the ultrasound process $\left(2 \mathrm{~kW}, 3 \mathrm{~min}\right.$, final temperature $52{ }^{\circ} \mathrm{C}$ ) may have damaged the oil contained in the microorganisms (Sheng et al., 2012). This was confirmed by Olkiewicz et al. (2015) who indicated no influence of ultrasonic pretreatment on four different types of sludge (primary, activated, blended (mix of primary and activated sludge) and stabilized). Chi et al. (2018) showed the important role of hexane addition for the improvement of biodiesel production and yield (in methyl esterification process). It mainly promoted the dissolution of FAMEs and improved the solubility of fat, however, it did not affect the transesterification reaction (FAMEs composition). It can also contribute to the extraction of more lipids from excess sludge (sludge from the bottom of a clarifier that returns back to the sludge treatment) or the following esterification reaction to produce biodiesel. Whereas Ma et al. (2016) reported that heptane is an important washing agent prior to the glycerin esterification and base catalyzed transesterification of scum. They showed that beside desulfurization performance, heptane washing also led to higher total FAMEs yield of higher quality.

The composition of fatty acids is fundamental for the production of biodiesel, and it directly influences the quality of the biodiesel (Menegazzo and Fonseca, 2019). Generally, highly unsaturated fats are expected to be more prone to oxidation, hydrolysis and lower gel formation than their saturated counterparts. The boiling points increase as the number of carbon atoms in the carbon chain increases, but decrease with the number of double bonds. Longer saturated fatty acids are excellent for biodiesel production, whereas unsaturated fatty acids are great for cold weather biodiesel production, therefore, a mixture is desirable (Gustone, 2004). Biodiesel can be used directly in conventional engines. Owing to its unique characteristics - having a higher cetane number (quality and performance of fuel, ignition speed) than average e.g. for the scum derived biodiesel 69.5 (Anderson et al., 2018), lubricity, positive ethanol fuel energy balance (net energy gain), higher flash point (more stable to autoignition), compatibility with the existing fuel distribution infrastructure and being free of sulfur - biodiesel is a promising renewable fuel offering a partial substitution to non-renewable petroleum-derived diesel fuel (Aghbashlo et al., 2016; Hajjari et al., 2014). In addition, biodiesel emits $20 \%$ less unburned hydrocarbons, $30 \%$ less $\mathrm{CO}$, and $50 \%$ less smoke compared to other diesel fuels (Datta and Mandal, 2016).

Conventional extraction processes on an industrial scale have several drawbacks such as insufficient recovery of extracts, solvent residues, hazardous waste production, and high energy consumption. The extraction rate strongly depends on the choice of solvents which are often not selective enough, resulting in a poor yield of bioactive extract relative to the high energy input required. Use of green chemical technologies (i.e., supercritical fluid extraction) to ensure maximum conversion efficiencies and higher selectivity at minimal energy consumption and waste production remains a challenge for biorefineries to become sustainable. An overview of the innovative research in this area applied to green extraction of natural products is given by Clark et al. (2012) and Rombaut et al. (2014), listing supercritical extraction, hydraulic pressure, instant controlled pressure drop process, microwave and ultrasound assisted extraction as emerging green biorefinery possibilities. Commercial perspectives of the most advanced method, processing of the lipid fraction based on supercritical technology, were reviewed in Temelli (2009). This approach maximizes the utilization and the value of various crops and biomass due to its high selectivity and high level of recovery without the presence of residual solvent. Supercritical $\mathrm{CO}_{2}$ extraction was identified to be more efficient in terms of FAMEs yield when processing algal biomass grown on domestic wastewater treatment plant effluent, compared to ultrasonic extraction with methanol/chloroform solvents or microwave assisted direct transesterification with methanol and $\mathrm{KOH}$ as solvents (Table 1 (Drira et al., 2016)). Literature on the use of emerging green biorefinery technologies is very limited. Research and innovation in sustainable recovery from urban wastewater is just beginning, bringing together various sectors towards more efficient and circular systems. More research is needed for further industrialization of the process.

\section{Research on wastewater-derived lipid biodiesel}

\subsection{Different stages of wastewater treatment as a potential feedstock for biodiesel production}

As lipids are readily removed by mixed microbial populations in WWTPs, total FAME yield showed a decreasing trend along the treatments: $30-60 \%$ originated from grease trap sludge (EWC (Pastore et al., 2015; Sangaletti-Gerhard et al., 2015)), 9-27\% from primary sludge (di Bitonto et al., 2019; Mondala et al., 2009; Olkiewicz et al., 2014, 2012; Pastore et al., 2013; Wang et al., 2016), 6-23\% from scum (from flotation tank) (Bi et al., 2015; di Bitonto et al., 2016; Wang et al., 2016), 0.5-6\% from activated sludge (Chi et al., 2018; di Bitonto et al., 2019; Dufreche et al., 2007; Hodaifa et al., 2013; Mondala et al., 2009; Olkiewicz et al., 2014, 2012; Pastore et al., 2013; Patiño et al., 2018; Revellame et al., 2010; Wang et al., 2016; Zhang et al., 2014), 1.2-11\% from blended sludge (primary and activated sludge in ratio 65:35) (Cea et al., 2015; di Bitonto et al., 2019; Olkiewicz et al., 2014, 2012; Zhang et al., 2014), and 1\% from stabilized sludge (anaerobic digestion of blended sludge) (Olkiewicz et al., 2012).

In general, primary sludge lipids originate from human waste and kitchen discharge, while the lipids in activated sludge, containing biomass, are considered to be derived from microbial cells (Turovskiy and Mathai, 2006). At first glance, fatty acid composition collected from various WWTPs worldwide and at different stages of treatment did not appear to be substantially different (Fig. 4). The content of palmitic (C16:0) and oleic acid (C18:1) were highest, with stearic (C18:0) and palmitoleic acid (C16:1) second. However, analysis 


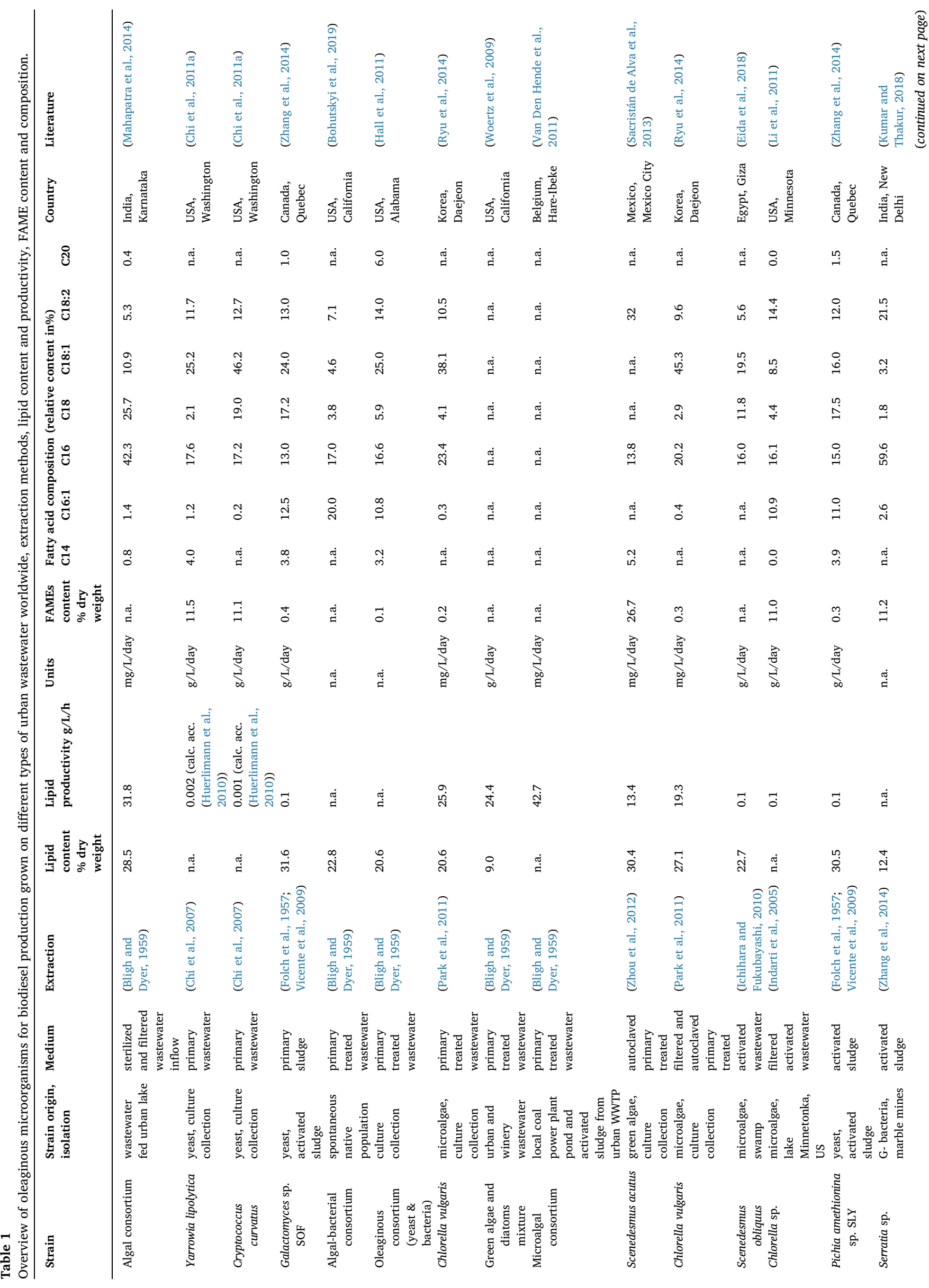




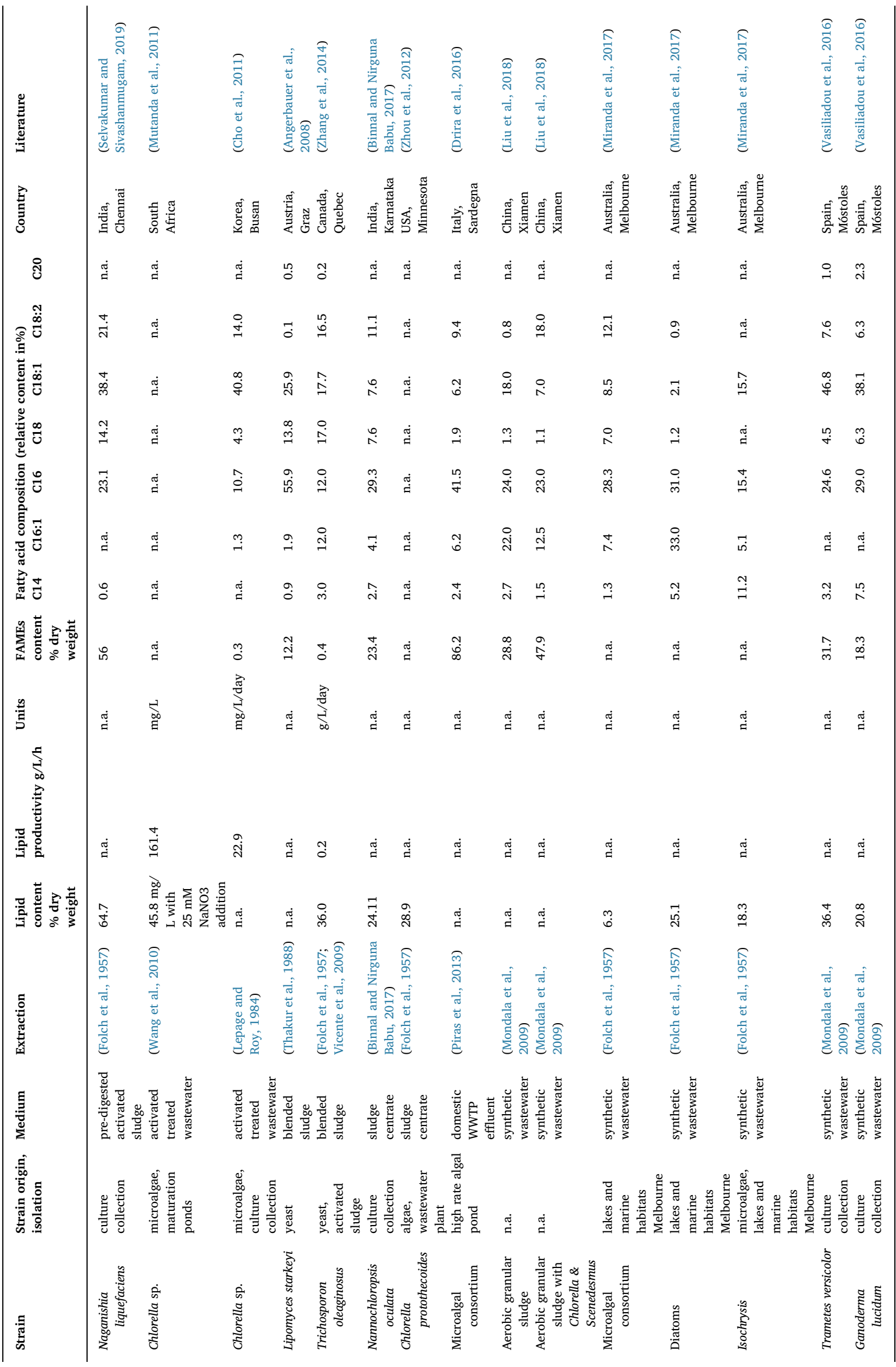




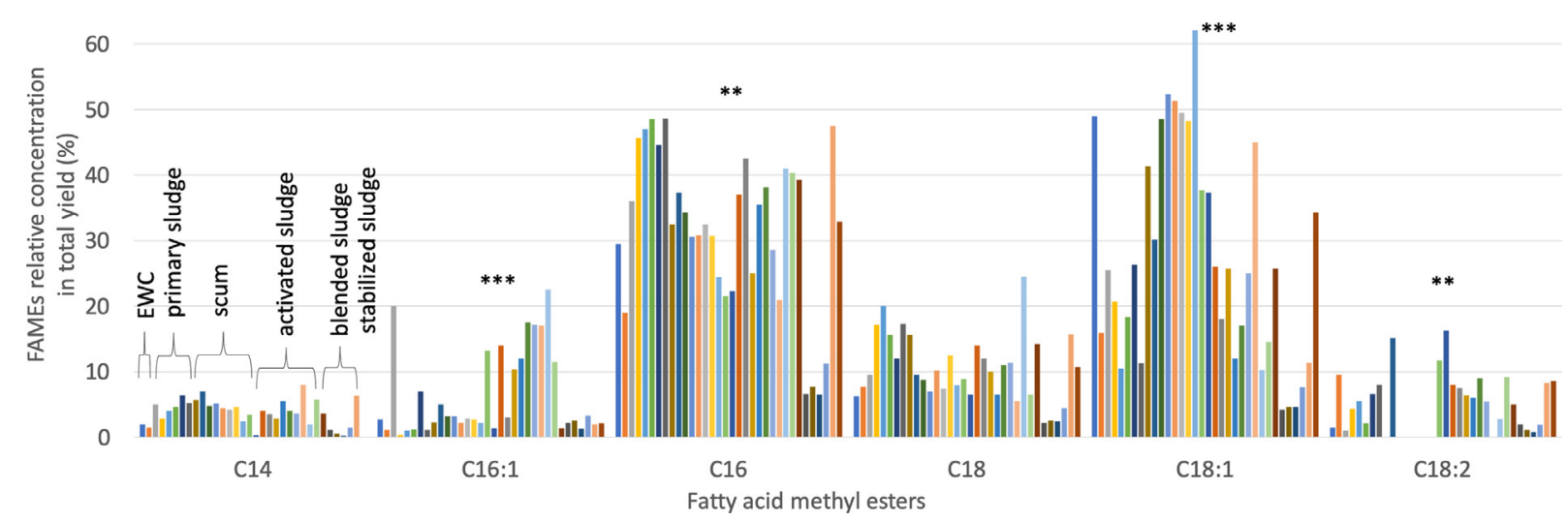

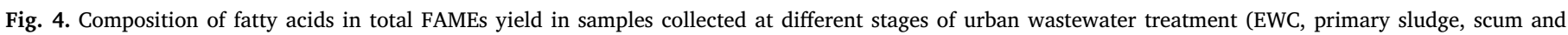

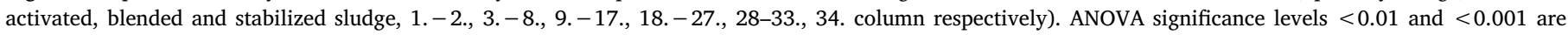
depicted with two and three asterisks, respectively.

of variance revealed the type of wastewater, meaning the stage of treatment when samples were taken, to be highly significant for some acids, especially oleic and palmitoleic $(p<0.001)$, palmitic and linoleic acid $(p<0.01)$.

\subsection{Oleaginous microorganisms}

Sustainable production of renewable and economically feasible biofuels is nowadays a hot topic globally. Understanding of resource limitation (land use, water scarcity) for first- and second-generation biofuels (mostly from food crops and non-edible biomass residues) gave rise to third-generation biofuels produced from non-edible feedstocks such as microalgae, bacteria, yeast and fungi. In addition to the metabolic synthesis of lipids (esp. fatty acids and triacylglycerols), oleaginous microorganisms (OMO) have been found to accumulate lipids, especially triacylglycerols, under specific cultivation conditions. This has established them as a comparable alternative source of oil due to their fast growth rate, large lipid content, minimal space requirements compared to animal or plant production, and potential further improvement due to metabolic engineering or genetic manipulation (Azadi et al., 2014; Cheirsilp et al., 2011; Chi et al., 2011b; Galafassi et al., 2012; Meng et al., 2009; Muniraj et al., 2015; Sergeeva et al., 2008). Beside lipid accumulation, OMO may contribute to macropollutant removal from wastewater, such as $\mathrm{NH}_{4}{ }^{+}, \mathrm{NO}_{3}{ }^{-}$and $\mathrm{PO}_{4}{ }^{3-}$, as these are vital for their growth (Thomas et al., 1984).

The high cost of biodiesel production using OMO has been the biggest obstacle for its industrialization (Wang et al., 2012). The process of biodiesel production from wastewater sludge and OMO involves many steps (microorganisms selection, cultivation, harvesting and dehydration, extraction of lipids, biodiesel production), of which lipid extraction is the most important and costly (Christie, 1993; Fon Sing et al., 2013; Molina Grima et al., 2003). Biodiesel production using OMO as a potential feedstock in the future has been intensively studied and reviewed thoroughly elsewhere (Azócar et al., 2010; Bellou et al., 2014; Cho and Park, 2018; Huang et al., 2017; Kumar et al., 2017; Li et al., 2008; Liang and Jiang, 2013; Ling et al., 2016; Mata et al., 2010; Meng et al., 2009; Olguín and Olguin Eugenia J, 2012; Qin et al., 2017; Rossi et al., 2011; Wang et al., 2012) and therefore was not the objective of this paper. On the other hand, literature referring to municipal wastewater as a growth substrate for OMO has only recently been published and is relatively sparse. Species selection may depend on various factors, such as the biomass and lipid productivity of each strain, characteristics of the wastewater, the origin of the strain, and its growth requirements for optimized biodiesel production.

Table 1 gives an overview of these strains studied worldwide. From the reported values, algae fed with filtered and sterilized wastewater treatment influent accomplished nutrient removal efficiency of up to $90 \%$, reaching a lipid content of $28.5 \%$ of dry weight biomass with a lipid productivity of $32 \mathrm{mg} / \mathrm{L} /$ day (Mahapatra et al., 2014). The lipid productivity in mechanically treated wastewater ('primary wastewater') is relatively low $(<0.002 \mathrm{~g} / \mathrm{L} /$ day $)$, but demonstrated feasibility of completely converting organic waste (removing undesirable nutrients) to lipid biomass and subsequently to biodiesel. The FAMEs content was over $11 \%$ of the harvested dry weight biomass of both yeast strains (Yarrowia lipolytica and Cryptococcus curvatus). In addition it was confirmed, that productivity can be significantly improved by optimization of culture conditions and control strategies (Chi et al., 2011a). For the yeast culture grown on primary sludge, the lipid productivity was a bit higher but with overall lower FAMEs content $(0.4 \%$ (Zhang et al., 2014)). Groups working with primary treated wastewater showed lipid content ranging from 9 to $32 \%$ for strains of diverse microbial origin, however, the disclosed content of FAMEs did not exceed $0.3 \%$ of dry weight biomass (Bohutskyi et al., 2019; Hall et al., 2011; Ryu et al., 2014; Van Den Hende et al., 2011; Woertz et al., 2009) with the exception of Scenedesmus acutus, where the efficiency of the transesterification reaction was almost 90\% (Table 1, (Sacristán de Alva et al., 2013). Microalgae grown on wastewater sampled from the aeration tank of the activated sludge process ('activated wastewater') showed lipid productivity of $0.1 \mathrm{~g} / \mathrm{L} /$ day, with extractable FAMEs content of 11\% from Chlorella sp. (Eida et al., 2018; Li et al., 2011). Activated sludge grown cultures possessed 12 to $31 \%$ lipid content, which in the case of Serratia sp. displayed $90 \%$ conversion to FAMEs, yielding $11 \%$ dry weight biomass (Kumar and Thakur, 2018; Zhang et al., 2014). High lipid and FAME content were reported for Naganishia liquefaciens yeast grown on pre-digested activated sludge (pre-treated with $\mathrm{NaOH}$ at $80{ }^{\circ} \mathrm{C}$ and ultrasonic digestion), yielding $65 \%$ and $56 \%$, respectively. Authors working with activated treated wastewater and Chlorella sp. reported lipid productivity ranging between 23 and $161 \mathrm{mg} / \mathrm{L} /$ day, despite the overall low FAMEs content of $0.3 \%$ (Cho et al., 2011; Mutanda et al., 2011). From blended sludge or centrate (liquid removed from thickened sludge) produced biomass, both Nannochloropsis oculata and Chlorella protothecoides were shown to have a high lipid accumulation potential, $24 \%$ and $29 \%$ of lipid content, respectively (Binnal and Nirguna Babu, 2017; Zhou et al., 2012). The data for Nannochloropsis (over $23 \%$ of FAMEs content) indicate its suitability for biodiesel production. The highest biodiesel yield (86\%) was obtained from a microalgal consortium with predominant Chlorella sp. grown on domestic WWTP effluent (Drira et al., 2016). High biodiesel yield (48\% and $29 \%$ of dry biomass respectively) was shown in algae-bacteria granular consortia with and without Chlorella and Scenedesmus as targeted algae grown on synthetic urban wastewater (Liu et al., 2018). Fungi cultures, Trametes versicolor and Ganoderma lucidum, yielded $32 \%$ and $18 \%$ of FAMEs, respectively 
Table 2

List of recent and ongoing projects founded by the European Union ordered chronologically.

\begin{tabular}{lllll}
\hline Project name & $\begin{array}{l}\text { Funding } \\
\text { agency }\end{array}$ & Duration time & $\begin{array}{l}\text { Total } \\
\text { budget in } €\end{array}$ & $\begin{array}{l}\text { Lead partner } \\
\text { country }\end{array}$ \\
\hline ALGFUEL & FP7-PEOPLE & $2011-2013$ & $1.5 \mathrm{E}+05$ & Spain \\
ALL-GAS & FP7- & $2011-2016$ & $1.2 \mathrm{E}+07$ & Spain \\
& ENERGY & & & \\
3CBIOTECH & ERC & $2011-2016$ & $1.5 \mathrm{E}+06$ & Ireland \\
BioAOPBDies & FP7-PEOPLE & $2012-2014$ & $1.7 \mathrm{E}+05$ & Spain \\
SMDR & FP7-PEOPLE & $2013-2017$ & $1.0 \mathrm{E}+05$ & United Kingdom \\
Watecco & ERC & $2014-2016$ & $1.5 \mathrm{E}+05$ & Israel \\
SOLENALGAE & ERC & $2016-2021$ & $1.4 \mathrm{E}+06$ & Italy \\
TO-SYN-FUEL & H2020 & $2017-2021$ & $1.5 \mathrm{E}+07$ & Germany \\
Usewaste & H2020 & $2018-2018$ & $7.1 \mathrm{E}+04$ & Israel \\
WOW! & NWE- & $2018-2021$ & $6.4 \mathrm{E}+06$ & Netherlands \\
& Interreg & & & \\
\hline
\end{tabular}

(Vasiliadou et al., 2016). Natural biofilms of freshwater consortia were shown to grow on synthetic wastewater with simultaneous accumulation of lipids, but only up to $6-25 \%$ of the dry weight content (Miranda et al., 2017).

The relative content of particular long chain fatty acids did not reveal any pattern, most likely due to the diverse species and broad medium characteristics. Nonetheless, a generally high percentage of palmitic (C16:0), oleic (C18:1), palmitoleic (C16:1) and stearic acid (C18:0) possessing relatively high cetane numbers (81.8, 61.1, 53.8 and 89.6, respectively (Giakoumis and Sarakatsanis, 2019)) suggest a high potential for the next generation of bioenergy feedstocks if further optimized. As shown previously, the fatty acid composition of different species has a significant effect on the characteristics of the produced biodiesel (Gouveia and Oliveira, 2009; Hu et al., 2008; Ötleş and Pire, 2001; Pratoomyot et al., 2005; Thomas et al., 1984). In addition, different nutritional and environmental factors, cultivation conditions and growth phases also affect the fatty acid composition. For example, nitrogen deficiency and salt stress was shown to induce accumulation of C18:1 in all treated microalgae species (Thomas et al., 1984), similarly $2 \%$ enrichment of $\mathrm{CO}_{2}$ led to $46 \%$ increase in lipid productivity of Scenedesmus obliquus with enhanced monounsaturated fatty acid production, mainly C18:1 (Han et al., 2016). Considering that cultivation, cell recovery and lipid extraction directly reflects the results obtained, the most appropriate methods for these operations must be applied (Menegazzo and Fonseca, 2019).

The life cycle of oleaginous microorganisms cultivated in a high $\mathrm{C} / \mathrm{N}$ ratio media is characterized by three distinct physiological phases (Dourou et al., 2018). During the balanced growth phase, when all nutrients are in excess, the microorganisms convert the $\mathrm{C}$ source mainly into cell biomass. Depletion of at least one of the essential nutrients (such as nitrogen, phosphorus, sulfur or magnesium) triggers the oleaginous phase, when C is converted into storage lipids (TAGs). Once the carbon gets depleted, cells initiate the degradation of lipids, entering the reserve lipid turnover phase. Therefore, beside the optimization of a fermentation protocol, being aware of the metabolic processes, it is possible to engineer strains in such a way that their metabolism is shifted towards desired pathways, increasing both the robustness and productivities of oleaginous strains. Strategies to increase the capacity of oleaginous microorganisms to accumulate lipids were recently reviewed by (Dourou et al., 2018; Lazar et al., 2018). Such strategies include suppression of competition to lipid biosynthesis pathways, over-expression of genes implicated in lipid (TAGs) synthesis, and inactivation of genes implicated in storage lipid turnover. Elimination of starch synthesis in Chlamydomonas strains increased the TAG production 10-fold (Li et al., 2010), and inactivation of glycogen synthesis in $Y$. lipolitica lead to an improvement of up to $60 \%$ in TAG accumulation compared to the original strain (Bhutada et al., 2017). Decline in the by-production of citric acid increased the lipid content in
Y. lipolitica 3-fold (Sagnak et al., 2018). Over-expression of genes implicated in lipid (TAGs) synthesis enhanced the lipid content in Y. lipolitica up to 60 fold (Blazeck et al., 2014) and 7 fold (Tai and Stephanopoulos, 2013). Inactivation of genes encoding for genes responsible for TAG degradation increased lipid content in the same strain from 0.7- to 4-fold (Beopoulos et al., 2008; Dulermo and Nicaud, 2011; Gajdoš et al., 2015; Wang et al., 2013). In addition, evolutionary strategies can be combined with genetic engineering for optimization of the lipid accumulation abilities of oleaginous microorganisms, as shown for $Y$. lipolitica. After 77 generations, the population was able to accumulate $30 \%$ more lipids than the starting strain (Daskalaki et al., 2019). Although not upscaled yet, these efforts may lead to a significant improvement in lipid accumulation in oleaginous microorganisms suitable as biodiesel feedstock.

\subsection{Latest research projects}

Recently, there has been a trend for new projects (listed in bold in this chapter) involving both academia and industry, trying to optimize the recovery of wastewater-derived lipids and scaling up to real conditions. An overview of the ongoing European projects is given in Table 2. What follows is a description of the projects. The project Wider business Opportunities for raw materials from Wastewater (NorthWest Europe Interreg project, 2018-2021, 6.5M€ (WOW!, 2018)) is fitting a conventional WWTP with a specially designed bioreactor and a selector to enhance growth and lipid accumulation of Microthrix parvicella. This Gram-positive filamentous bacterium is mostly well known for causing bulking and foaming problems in WWTPs, beside its ability to dominate activated sludge. On the other hand, this strain can effectively accumulate long chain fatty acids. The aim is therefore to upscale biomass of Microthrix accumulating lipids and simultaneous accumulation of lipids from wastewater, gaining both a net profit and a lipid related maintenance-free wastewater processes. Intimate coupling of biological advanced oxidation process for environmental de-pollution and biodiesel production (7th Framework Programme, 2012-2014, 170K€ (BioAOPBDies, 2012)) was aimed at biological/ advanced oxidation removal of micropollutants from wastewater effluent and subsequent use of the produced biomass during processes such as a lipid feedstock for biodiesel production. Different types of biomass were used for this purpose, such as mixed microbial cultures or fungi (Trametes versicolor and Ganoderma lucidum, Table 1). Biodiesel production from microalgae (7th Framework Programme, 2011-2013, 150K€ (ALGFUEL, 2011)) is aimed at identification of microalgae species suitable for biodiesel production in different media (such as the sea, brackish and wastewater) and to improve the understanding of the main mechanisms driving formation of microalgal TAGs productivity. The demonstration of Waste Biomass to Synthetic Fuels and Green Hydrogen project (Horizon 2020, 2017-2021, 14.5M $€$ (TO-SYN-FUEL, 2017)) aims to build up, operate and demonstrate conversion of organic waste biomass, mainly sewage sludge, into biofuels. The project is implementing a new integrated process combining Thermo-Catalytic Reforming with hydrogen separation through pressure swing adsorption, and hydro deoxygenation, to produce fully equivalent gasoline, biodiesel and hydrogen. Industrial scale demonstration of sustainable algae cultures for biofuel production (7th Framework Programme, 2011-2016, 12M€ (ALL-GAS, 2011)) proposed a large-scale production of biodiesel and other bio-fuels on microalgae cultures fed with wastewater influent. The specified algae yield was estimated to be $100 \mathrm{t} / \mathrm{ha}$ /year with a net oil content of $20 \%$. Spinning Mesh Disc Reactors, a new paradigm for photocatalytic and enzymatic reaction intensification (7th Framework Programme, 2013-2017, 100K€ (SMDR, 2013)), uses a high surface area rotating mesh supporting a catalyst to create process intensification at rapid mixing and increased heat and mass transfer rates compared to conventional reactors. The project is focused on degradation of pharmaceuticals in wastewater and enzymatic biochemical transformation of 
waste oils to biodiesel. Improving photosynthetic solar energy conversion in microalgal cultures for the production of biofuels and high value products (European Research Council, 2016-2021, $\sim 1.4 \mathrm{M} €$ (SOLENALGAE, 2016)) is aimed towards cultivation of biomass at reduced costs, therefore different microalgal strains are cultivated on various nutrient sources derived from urban wastewater, sewage sludge or agro-waste. Cold carbon catabolism of microbial communities underpinning a sustainable bioenergy and biorefinery economy (European Research Council, 2011-2016, 1.5M€ (3CBIOTECH, 2011)) is applying classical microbiological, physiological and real-time polymerase chain reaction-based assays to qualitatively and quantitatively characterize microbial communities involved in biorefinery conversion of waste biomass (including municipal sewage). Water column profiler for quantification of photosynthesis and biomass of phytoplankton in natural and man made water bodies (European Research Council, 2014-2016, 150K€ (Watecco, 2014)) can provide fast, real time data on the efficiency of photobioreactors for proliferation of algal cultures to attain high yields of their target products (e.g., production of biodiesel in sewage treatment systems). Patented modified-immobilized enzymes used in the production of biodiesel at commercial scales using any type of feedstock (Horizon 2020, May-September 2018, 70K€ (Usewaste, 2018)) investigates enzyme technology for a continuous, cost-effective production of biodiesel using any grade feedstock (0-100\% FFAs).

\section{Market potential}

\subsection{Assessment of potential supply}

Current wastewater treatment systems are mainly based on Activated Sludge Technology. This technology relies on the fact that the microbial community in the reactors - activated sludge - uses organic material from the influent for their growth and energy production. The following assessment of the potential biodiesel production and potential supply is based on this initial situation.

The potential supply of biodiesel from urban wastewater-derived lipids was calculated based on these facts i) $30-40 \%$ of COD $(120 \mathrm{~g} / \mathrm{d} /$ PE) in urban wastewater influent is FOG (Raunkjær et al., 1994), ii) the population of the EU-28 in 2018 was estimated to be 512,710,966 (Eurostat, 2019a), iii) $80 \%$ of the population (EU-15) is connected to WWTPs (Eurostat, 2019b), and iv) the average possible biodiesel production at different stages of wastewater treatment (reviewed in Chapter 3.1). A summary of the assessment data are given in Table 3. Results on potential annual market supply indicated $3-41410^{4}$ tons (minimum for activated and maximum for EWC sludge) of extractable biodiesel from wastewater.

The potential demand for wastewater derived biodiesel can be estimated from the current biodiesel production statistics. With the prospect to transform WWTPs into biorefineries and considering the expected biodiesel demand is $14.810^{6}$ tons (Eurostat, 2019c), we may cover on average up to $1.5,2.9,6.2,6.7$ and $24.4 \%$ from activated, blended, primary, scum and EWC sludge, respectively, of the European biodiesel market from wastewater-derived lipids. When implementing an optimized selector in a conventional activated sludge plant which fosters the utilization of oleaginous biomass, the overall biodiesel yield may be even higher. Assuming a higher percentage of FOG is incorporated, thereby increasing the percentage of lipids being harvested. Such an amount cannot be ignored, and if efficiently implemented, it could represent an exploitable resource for biofuel production, an important and desired step towards a circular economy (EC, 2016, 2015).

\subsection{Possible risks}

The main possible risk for the wastewater treatment process with an implemented biorefinery unit may be a decrease in the production of biogas. For the calculation, we have considered the overall sludge production in the EU-28 to be $9.0410^{6}$ tons of dry matter/year (Eurostat, 2018), constituting 70\% volatile solids (Jenicek et al., 2012). Of the sludge production, $50 \%$ accounts for primary and $50 \%$ for activated sludge, of which $6 \%$ and $8 \%$ respectively, contribute to the FOG content (Burton et al., 2013). Applying a theoretical model assuming the maximum substrate degradation and complete conversion to biogas, the potential biogas yield from lipids would be $1337 \mathrm{~L} / \mathrm{kg}$ of volatile solids (Lübken et al., 2010), meaning that just the FOG fraction generates 2.5 and $3.410^{11} \mathrm{~L}$ of biogas for primary and activated sludge, respectively. While the total European biogas production from urban sewage sludge is estimated to be 18-25 L/PE/d (Bolzonella et al., 2005; Haberkern et al., 2008; Lindtner, 2008; VSA - Verband Schweizer Abwasserund Gewässerschutzfachleute, 2010), the overall EU-28 biogas yield amounts to $3.4-4.710^{12} \mathrm{~L}$ /year. Finally, the potential biogas yield loss arising from the FOG fraction removed from the sludge prior to the anaerobic digestion, would correspond to $13-18 \%$.

Another potential risk may be the implementation of a selector for the generation of a lipid rich sludge. If not operated anticipatorily, the elimination of carbon and other nutrients in the bioreactor could lead to substrate depletion, esp. for the denitrification step where a specific C/ $\mathrm{N}$-ratio is necessary. Another possible (although improbable) risk is the formation of floating sludge in the conventional part of the plant, which has bad settling properties and therefore cannot be removed in the settling tank. Additionally, a proper membrane or a detention mechanism is needed for selectors in order to avoid leakage or unintentional inoculation of subsequent treatment steps with cultivated oleaginous microorganisms. The current status of the technique gaining lipids from wastewater has Technology Readiness Level (TRL) of around 5, and thus a risk analysis together with a mitigation plan can be considered only indicative.

\section{Towards an economy policy}

The possible use of lipids from sewage sludge to produce a marketable product such as biodiesel has to be supported by solid legislation, which is not yet in place. Existing EU legislation does not encourage more efficient use of valuable products from wastewater as an objective (Economical Water Upcycling), especially due to the lack of market access information. Hence, further steps have to be taken to foster resources management.

So far, the only specified objective is related to phosphorus and nitrogen. It was forecast that the recovery of phosphorus from urban wastewater could reach up to $15 \%$ of current demand (Kabbe, 2015). This aim is even higher in Luxembourg, with $35 \%$ expected reuse by 2020 (Hansen et al., 2014), and up to 3\% of mineral nitrogen fertilizer inputs (Sutton et al., 2011). Legislation in general has been more receptive to similar changes in the last few decades, stimulated by social discussions on sustainability. To this end, a policy on possible reuse of lipids from sewage sludge is expected to be initiated through the 'back door' rather than directly from water or waste management-based directives.

The importance of positive principles for circularity in legislation is high. Resource scarcity, environmental limits as well as climate change have in fact been pushing policymakers and corporations (e.g., EIB, KPMG, CEC4Europe, McKinsey) for new economic concepts and new production, distribution and recycling mechanisms, aimed at reducing the environmental impact of human activity (Chambre de Commerce Luxembourg, 2016; Nguyen Doan, 2019). Circularity is on the way to becoming part of the European and national legislative frameworks through a range of instruments/studies containing a set of information on the legislative framework as well as recommendations on how to improve it. Here we mention the pioneering ones: i) in March 2014, the UK presented "Remanufacturing. Towards a Resource Efficient Economy" as one of the elements of a circular economy and highlighted widespread market and regulatory barriers which hamper its uptake 
Table 3

Summary of assessment data for market potential study.

\begin{tabular}{|c|c|c|c|}
\hline & Variable & Value & Units \\
\hline & Predicted biodiesel consumption in 2018 (EU-28) & $14.8 E+6$ & $\mathrm{t}$ \\
\hline & Population number in 2018 (EU-28) & $512.7 E+6$ & PE \\
\hline & FOG portion of COD & $30-40$ & $\%$ \\
\hline & COD load in urban WWTP & 120 & $\mathrm{~g} / \mathrm{PE} /$ day \\
\hline & Corresponding load of FOG & $36-48$ & $\mathrm{~g} / \mathrm{PE} / \mathrm{day}$ \\
\hline & Population in EU-15 connected to sewerage system & 80 & $\%$ \\
\hline & EWC from oil-water separator & 57.6 & $\%$ \\
\hline \multirow{6}{*}{ Total FAME yield } & Primary sludge & $9-19$ & $\%$ \\
\hline & Scum & $6-23$ & $\%$ \\
\hline & Activated sludge & $0.5-6$ & $\%$ \\
\hline & Blended sludge & $1.2-11$ & $\%$ \\
\hline & Stabilized sludge & 1 & $\%$ \\
\hline & Annual amount of FOG processed in WWTPs (EU-28) & $539.0-718.6 E+4$ & $\mathrm{t} /$ year \\
\hline \multirow[t]{6}{*}{ Potential biodiesel production } & EWC from oil-water separator & $310.4-414.0 E+4$ & $\mathrm{t} /$ year \\
\hline & Primary sludge & $48.5-136.5 E+4$ & $\mathrm{t} /$ year \\
\hline & Scum & $32.3-165.3 E+4$ & $\mathrm{t} /$ year \\
\hline & Activated sludge & $2.7-43.1 E+4$ & $\mathrm{t} /$ year \\
\hline & Blended sludge & $6.5-79.0 E+4$ & $\mathrm{t} /$ year \\
\hline & Stabilized sludge & $5.4-7.2 E+4$ & $\mathrm{t} /$ year \\
\hline \multirow[t]{6}{*}{ Potential cover of biodiesel demand } & EWC from oil-water separator & $20.9-27.9$ & $\%$ \\
\hline & Primary sludge & $3.3-9.2$ & $\%$ \\
\hline & Scum & $2.2-11.1$ & $\%$ \\
\hline & Activated sludge & $0.2-2.9$ & $\%$ \\
\hline & Blended sludge & $0.4-5.3$ & $\%$ \\
\hline & Stabilized sludge & $0.4-0.5$ & $\%$ \\
\hline
\end{tabular}

(All Party Parliamentary Sustainable Resource Group, 2014), ii) in June, the European Union introduced "Regulations" (EC, 2014a), a new legislative approach for $\mathrm{R} \& \mathrm{D}$, to encourage environmental protection and rational use of resources, and requested member states to integrate these into national legislation, iii) in July, the European Commission issued a publication "Towards a circular economy: A zero waste program for Europe" appealing to the member states that strong policy signals are needed to create longer-term opportunities for recyclable materials that could re-enter the economy at competitive prices contributing to the development of markets for the supply of high quality activated raw materials (EC, 2014b); and iv) in August, the European Commission launched a "Scoping study to identify potential circular economy actions, priority sectors, material flows and value chains" to provide an initial assessment of potential priorities and policy options to support the transition to circular economy in the EU (EC, 2014c). As a follow up, the Luxembourg based company, KPMG, (KPMG, 2014) recognized "internalization of externalities" having the most significant impact on the legislative framework for companies and agencies internationally.

In 2015, during Luxembourg's EU presidency, particular focus was placed on the circular economy and the financing of the transition towards it (Grand Duchy of Luxembourg, 2015). The key European policies comprised of four legislative proposals introducing new wastemanagement targets regarding reuse, recycling and landfilling, the Circular Economy Package, were presented by the European Commission in December 2015. So far, no concrete legislative barriers towards lipids or other carbon-based raw materials derived from wastewater were identified. Quality criteria as well as change of status (from waste) still have to be defined. However, following the good example of demolition waste (Luxembourg, 2013) and how the legislation was adapted in Luxembourg (SeRaMCo, 2019), it can be expected that similar tendencies and changes in other sectors and countries will follow if well stimulated.

\section{Conclusion}

In the near future, the world will face a series of major problems, concerning resource scarcity, environmental limits as well as climate change and change in the job market. This study addresses challenges and possibilities for transition in the urban water cycle, where lipids are recovered from wastewater and used as a raw material for biodiesel production. Wastewater sewage sludge has a high potential as a possible feedstock because of its disposal necessity, low cost and expected constant increase in the future. For the biotechnological production of lipids, selected oleaginous strains are able to grow on urban wastewater. Optimizing growth conditions may lead to obtaining higher biomass and lipid yields and productivity. The process of harvesting sludge or cells and releasing lipids from biomass needs to be efficient and economically viable. The circular use of raw materials from wastewater requires politicians to determine legislation in favor of valueadded products to promote sustainable development while lightening the burden of production based on the use of limited resources. Also, WWTP operators need to make certain changes in their way of thinking and operating of facilities.

\section{Declaration of Competing Interest}

The authors declare that they have no known competing financial interests or personal relationships that could have appeared to influence the work reported in this paper.

\section{Acknowledgements}

The presented outcomes are part of the North-West European Interreg project VB WOW (Wider business Opportunities for raw materials from Wastewater - NWE project number 619). The authors would like to acknowledge and appreciate the anonymous reviewers for their constructive comments and thank Nina Grunova for her assistance with graphic design.

\section{References}

3 CBIOTECH, 2011. Cold Carbon Catabolism of Microbial Communities Underpinning a Sustainable Bioenergy and Biorefinery Economy [WWW Document]. URL https:// cordis.europa.eu/project/rcn/98742/factsheet/en (accessed 10.11.19).

Adams, C., Peters, J.F., Rand, M.C., Schroer, B.J., Ziemke, M.C., 1983. Investigation of 
soybean oil as a diesel fuel extender: endurance tests. J. Am. Oil Chem. Soc. 60, 1574-1579. https://doi.org/10.1007/BF02666588.

Aghbashlo, M., Shamshirband, S., Tabatabaei, M., Yee, P.L., Larimi, Y.N., 2016. The use of ELM-WT (extreme learning machine with wavelet transform algorithm) to predict exergetic performance of a DI diesel engine running on diesel/biodiesel blends containing polymer waste. Energy 94, 443-456. https://doi.org/10.1016/J.ENERGY. 2015.11.008.

Ajanovic, A., 2013. Renewable fuels - a comparative assessment from economic, energetic and ecological point-of-view up to 2050 in EU-countries. Renew. Energy 60, 733-738. https://doi.org/10.1016/j.renene.2013.06.012.

ALGFUEL, 2011. Biodiesel Production from Microalgae [WWW Document]. URL. https://cordis.europa.eu/project/rcn/94675/reporting/en (accessed 10.3.19).

All Party Parliamentary Sustainable Resource Group, 2014. Remanufacturing. Towards a Resource Efficient Economy.

ALL-GAS, 2011. Industrial Scale Demonstration of Sustainable Algae Cultures for Biofuel Production [WWW Document]. URLhttp://www.all-gas.eu/en/home(accessed 10. 3.19).

Anderson, E., Addy, M., Chen, P., Ruan, R., 2018. Development and operation of innovative scum to biodiesel pilot-system for the treatment of floatable wastewater scum. Bioresour. Technol. 249, 1066-1068. https://doi.org/10.1016/j.biortech. 2017.10.075.

Andreasen, K., Nielsen, P.H., 2000. Growth of Microthrix parvicella in nutrient removal activated sludge plants: studies of in situ physiology. Water Res 34, 1559-1569 10.1016/S0043-1354(99)00319-X.

Angerbauer, C., Siebenhofer, M., Mittelbach, M., Guebitz, G.M., 2008. Conversion of sewage sludge into lipids by Lipomyces starkeyi for biodiesel production. Bioresour. Technol. 99, 3051-3056. https://doi.org/10.1016/j.biortech.2007.06.045.

Aria, M., Cuccurullo, C., 2017. bibliometrix: an R-tool for comprehensive science mapping analysis. J. Informetr. 11, 959-975. https://doi.org/10.1016/j.joi.2017.08.007.

Azadi, P., Brownbridge, G., Mosbach, S., Smallbone, A., Bhave, A., Inderwildi, O., Kraft, M., 2014. The carbon footprint and non-renewable energy demand of algae-derived biodiesel. Appl. Energy 113, 1632-1644. https://doi.org/10.1016/J.APENERGY. 2013.09.027.

Azócar, L., Ciudad, G., Heipieper, H.J., Navia, R., 2010. Biotechnological processes for biodiesel production using alternative oils. Appl. Microbiol. Biotechnol. 88, 621-636. https://doi.org/10.1007/s00253-010-2804-z.

Beldean-Galea, M.S., Vial, J., Thiébaut, D., Coman, V., 2013. Characterization of the fate of lipids in wastewater treatment using a comprehensive GC $\times$ GC/qMS and statistical approach. Anal. Methods 5, 2315-2323. https://doi.org/10.1039/C3AY00060E.

Bellou, S., Baeshen, M.N., Elazzazy, A.M., Aggeli, D., Sayegh, F., Aggelis, G., 2014. Microalgal lipids biochemistry and biotechnological perspectives. Biotechnol. Adv. 32, 1476-1493. https://doi.org/10.1016/j.biotechadv.2014.10.003.

Beopoulos, A., Mrozova, Z., Thevenieau, F., Le Dall, M.T., Hapala, I., Papanikolaou, S., Chardot, T., Nicaud, J.M., 2008. Control of lipid accumulation in the yeast Yarrowia lipolytica. Appl. Environ. Microbiol. 74, 7779-7789. https://doi.org/10.1128/AEM. 01412-08.

Berrios, M., Siles, J., Martín, M.A., Martín, A., 2007. A kinetic study of the esterification of free fatty acids (FFA) in sunflower oil. Fuel 86, 2383-2388. https://doi.org/10.1016/ J.FUEL.2007.02.002.

Bhutada, G., Kavšček, M., Ledesma-Amaro, R., Thomas, S., Rechberger, G.N., Nicaud, J.M., Natter, K., 2017. Sugar versus fat: elimination of glycogen storage improves lipid accumulation in Yarrowia lipolytica. FEMS Yeast Res. 17. https://doi.org/10. 1093/femsyr/fox020. fox020.

Bi, C., hao, Min, M., Nie, Y., Xie, Q., long, Lu, Q., Deng, X., yuan, Anderson, E., Li, D., Chen, P., Ruan, R., 2015. Process development for scum to biodiesel conversion. Bioresour. Technol. https://doi.org/10.1016/j.biortech.2015.01.081.

Binnal, P., Nirguna Babu, P., 2017. Cultivation of Nannochloropsis oculata in centrate and conversion of its lipids to biodiesel in a low-cost microwave reactor. Biofuels 1-14. https://doi.org/10.1080/17597269.2017.1316141.

BioAOPBDies, 2012. Intimate Coupling of Biological Advanced Oxidation Process for Environmental De-Pollution and Biodiesel Production [WWW Document]. URL. https://cordis.europa.eu/project/rcn/98888/factsheet/en (accessed 10.3.19).

Blazeck, J., Hill, A., Liu, L., Knight, R., Miller, J., Pan, A., Otoupal, P., Alper, H.S., 2014. Harnessing Yarrowia lipolytica lipogenesis to create a platform for lipid and biofuel production. Nat. Commun. 5. https://doi.org/10.1038/ncomms4131.

Bligh, E.G., Dyer, W.J., 1959. A rapid method of total lipid extraction and purification. Can. J. Biochem. Physiol. 37, 911-917 dx.doi.org/10,1139/cjm2014-0700.

Bohutskyi, P., Phan, D., Spierling, R.E., Kopachevsky, A.M., Bouwer, E.J., Lundquist, T.J., Betenbaugh, M.J., 2019. Production of lipid-containing algal-bacterial polyculture in wastewater and biomethanation of lipid extracted residues: enhancing methane yield through hydrothermal pretreatment and relieving solvent toxicity through co-digestion. Sci. Total Environ. 653, 1377-1394. https://doi.org/10.1016/j.scitotenv.2018. 11.026.

Bolzonella, D., Pavan, P., Battistoni, P., Cecchi, F., 2005. Mesophilic anaerobic digestion of waste activated sludge: influence of the solid retention time in the wastewater treatment process. Process Biochem. 40, 1453-1460. https://doi.org/10.1016/J. PROCBIO.2004.06.036.

Burton, F., Tchobanoglous, G., Tsuchihashi, R., Stensel, H.D., 2013. Wastewater Engineering: Treatment and Resource Recovery, fifth ed. McGraw-Hill Science/ Engineering/Math, Boston, MA.

Huang, C., Luo, M.T., Chen, X.F., Xiong, L., Li, X.M., Chen, X.De, 2017. Recent advances and industrial viewpoint for biological treatment of wastewaters by oleaginous microorganisms. Bioresour. Technol. 232, 398-407. https://doi.org/10.1016/j. biortech.2017.02.055.

Cea, M., Sangaletti-Gerhard, N., Acuña, P., Fuentes, I., Jorquera, M., Godoy, K., Osses, F., Navia, R., 2015. Screening transesterifiable lipid accumulating bacteria from sewage sludge for biodiesel production. Biotechnol. Rep. 8, 116-123. https://doi.org/10. 1016/j.btre.2015.10.008.

Chambre de Commerce Luxembourg, 2016. Digital transformation in business and society. Actual. Tendences. Bull. Économique la Chamb. Commer 196.

Chang, C.C., Wan, S.W., 1947. China's Motor Fuels from Tung Oil. Ind. Eng. Chem. 39, 1543-1548. https://doi.org/10.1021/ie50456a011.

Cheirsilp, B., Suwannarat, W., Niyomdecha, R., 2011. Mixed culture of oleaginous yeast Rhodotorula glutinis and microalga Chlorella vulgaris for lipid production from industrial wastes and its use as biodiesel feedstock. N. Biotechnol. 28, 362-368. https://doi.org/10.1016/J.NBT.2011.01.004.

Chi, X., Li, A., Li, M., Ma, L., Tang, Y., Hu, B., Yang, J., 2018. Influent characteristics affect biodiesel production from waste sludge in biological wastewater treatment systems. Int. Biodeterior. Biodegrad. 132, 226-235. https://doi.org/10.1016/J. IBIOD. 2018.04.010.

Chi, Z., Pyle, D., Wen, Z., Frear, C., Chen, S., 2007. A laboratory study of producing docosahexaenoic acid from biodiesel-waste glycerol by microalgal fermentation. Process Biochem 42, 1537-1545. https://doi.org/10.1016/j.procbio.2007.08.008.

Chi, Z., Zheng, Y., Jiang, A., Chen, S., 2011a. Lipid production by culturing oleaginous yeast and algae with food waste and municipal wastewater in an integrated process. Appl. Biochem. Biotechnol. 165, 442-453. https://doi.org/10.1007/s12010-011 9263-6.

Chi, Z., Zheng, Y., Ma, J., Chen, S., 2011b. Oleaginous yeast Cryptococcus curvatus culture with dark fermentation hydrogen production effluent as feedstock for microbial lipid production. Int. J. Hydrog. Energy 36, 9542-9550. https://doi.org/10. 1016/J.IJHYDENE.2011.04.124.

Chipasa, K.B., Mędrzycka, K., 2006. Behavior of lipids in biological wastewater treatment processes. J. Ind. Microbiol. Biotechnol. 33, 635-645. https://doi.org/10.1007/ s10295-006-0099-y.

Chipasa, K.B., Medrzycka, K., 2008. Characterization of the fate of lipids in activated sludge. J. Environ. Sci. 20, 536-542 10.1016/S1001-0742(08)62091-4.

Cho, H.U., Park, J.M., 2018. Biodiesel production by various oleaginous microorganisms from organic wastes. Bioresour. Technol. 256, 502-508. https://doi.org/10.1016/j. biortech.2018.02.010.

Cho, S., Luong, T.T., Lee, D., Oh, Y.K., Lee, T., 2011. Reuse of effluent water from a municipal wastewater treatment plant in microalgae cultivation for biofuel production. Bioresour. Technol. 102, 8639-8645. https://doi.org/10.1016/j.biortech.2011. 03.037.

Christie, W.W., 1993. Preparation of lipid extracts tissue. Adv. Lipid Methodol. 2 $195-213$.

Clark, J.H., Luque, R., Matharu, A.S., 2012. Green chemistry, biofuels, and biorefinery. Annu. Rev. Chem. Biomol. Eng. 3, 183-207. https://doi.org/10.1146/annurevchembioeng-062011-081014.

Crossley, A., Heyes, T.D., Hudson, B.J.F., 1962. The effect of heat on pure triglycerides. J. Am. Oil Chem. Soc. 39, 9-14. https://doi.org/10.1007/BF02633339.

Daskalaki, A., Perdikouli, N., Aggeli, D., Aggelis, G., 2019. Laboratory evolution strategies for improving lipid accumulation in Yarrowia lipolytica. Appl. Microbiol. Biotechnol. 103, 8585-8596. https://doi.org/10.1007/s00253-019-10088-7.

Datta, A., Mandal, B.K., 2016. A comprehensive review of biodiesel as an alternative fuel for compression ignition engine. Renew. Sustain. Energy Rev. 57, 799-821. https:// doi.org/10.1016/J.RSER.2015.12.170.

di Bitonto, L., Locaputo, V., D'Ambrosio, V., Pastore, C., 2019. Direct Lewis-Brønsted acid ethanolysis of sewage sludge for production of liquid fuels. Appl. Energy, 114163. https://doi.org/10.1016/J.APENERGY.2019.114163.

di Bitonto, L., Lopez, A., Mascolo, G., Mininni, G., Pastore, C., 2016. Efficient solvent-less separation of lipids from municipal wet sewage scum and their sustainable conversion into biodiesel. Renew. Energy 90, 55-61. https://doi.org/10.1016/j.renene. 2015.12.049.

Dignac, M.F., Ginestet, P., Rybacki, D., Bruchet, A., Urbain, V., Scribe, P., 2000. Fate of wastewater organic pollution during activated sludge treatment: nature of residual organic matter. Water Res. 34, 4185-4194 10.1016/S0043-1354(00)00195-0.

Dourou, M., Aggeli, D., Papanikolaou, S., Aggelis, G., 2018. Critical steps in carbon metabolism affecting lipid accumulation and their regulation in oleaginous microorganisms. Appl. Microbiol. Biotechnol. 102, 2509-2523. https://doi.org/10.1007/ s00253-018-8813-z.

Drira, N., Piras, A., Rosa, A., Porcedda, S., Dhaouadi, H., 2016. Microalgae from domestic wastewater facility's high rate algal pond: lipids extraction, characterization and biodiesel production. Bioresour. Technol. 206, 239-244. https://doi.org/10.1016/j. biortech.2016.01.082.

Dueholm, T.E., Andreasen, K.H., Nielsen, P.H., 2001. Transformation of lipids in activated sludge. Water Sci. Technol. 43, 165-172.

Dufreche, S., Hernandez, R., French, T., Sparks, D., Zappi, M., Alley, E., 2007. Extraction of lipids from municipal wastewater plant microorganisms for production of biodiesel. J. Am. Oil Chem. Soc. 84, 181-187. https://doi.org/10.1007/s11746-0061022-4.

Dulermo, T., Nicaud, J.M., 2011. Involvement of the G3P shuttle and B-oxidation pathway in the control of TAG synthesis and lipid accumulation in Yarrowia lipolytica. Metab. Eng. 13, 482-491. https://doi.org/10.1016/j.ymben.2011.05.002.

DWA, 2016. DWA-Regelwerk. Bemessung von einstufigen Belebungsanlagen.

EC, 1999. Council Directive 1999/31/EC on the landfill of waste. Off. J. Eur. Commun. 182.

EC, 2009. Directive 2009/28/EC on the Promotion of the Use of Energy From Renewable Sources.

EC, 2014. Regulations. Commission regulation (EU) No 651/2014.

EC, 2014. Communication from the Commission to the European Parliament, the Council, the European Economic and Social Committee and the Committee of the Regions. Towards a Circular Economy: A Zero Waste Programme for Europe. 
EC, 2014. Scoping Study to Identify Potential Circular Economy Actions, Priority Sectors, Material Flows and Value Chains.

EC, 2015. Closing the Loop - An EU action plan for the Circular Economy. COM/2015/ 0614.

EC, 2016. Circular Economy Strategy.

Eida, M.F., Darwesh, O.M., Matter, I.A., 2018. Cultivation of oleaginous microalgae Scenedesmus obliquus on secondary treated municipal wastewater as growth medium for biodiesel production. J. Ecol. Eng. 19, 38-51. https://doi.org/10.12911/ $22998993 / 91274$.

Engler, C.R., Johnson, L.A., Lepori, W.A., Yarbrough, C.M., 1983. Effects of processing and chemical characteristics of plant oils on performance of an indirect-injection diesel engine. J. Am. Oil Chem. Soc. 60, 1592-1596. https://doi.org/10.1007/ BF02666591.

EPA, 2015. Waste classification. Liste of Waste \& Deterining if Waste is Hazardous or Nonhazardous.

EU, 2008. Directive 2008/98/EC on waste. Off. J. Eur. Union 312.

EU, 2018. Directive (EU) 2018/2001 of the European Parliament and of the Council on the promotion of the use of energy from renewable sources. Off. J. Eur. Union 328, 82-209.

Eurostat, 2018. Sewage Sludge Production and Disposal [WWW Document]. URL. https://ec.europa.eu/eurostat/web/products-datasets/product?code = env_ww_spd (accessed 10.7.19).

Eurostat, 2019 a. Population and population change statistics [WWW Document]. URLhttps://ec.europa.eu/eurostat/statistics-explained/index.php/Population_and_ population_change_statistics(accessed 10.7.19).

Eurostat, 2019 b. Water Statistics [WWW Document]. URL https://ec.europa.eu/eurostat/statistics-explained/index.php/Water_statistics\#Wastewater_treatment (accessed 10.7.19).

Eurostat, 2019 c. Energy Balances - Early Estimates [WWW Document]. URL https:// ec.europa.eu/eurostat/statistics-explained/index.php?title = Energy_balances_-_early_estimates (accessed 10.7.19).

Folch, J., Lees, M., Stanley, Sloane, G.H., 1957. A simple method for the isolation and purification of total lipides from animal tissues. J. Biol. Chem. 226, 497-509.

Fon Sing, S., Isdepsky, A., Borowitzka, M.A., Moheimani, N.R., 2013. Production of biofuels from microalgae. Mitig. Adapt. Strategy Glob. Change 18, 47-72. https:// doi.org/10.1007/s11027-011-9294-x.

Gajdoš, P., Nicaud, J.M., Rossignol, T., Čertík, M., 2015. Single cell oil production on molasses by Yarrowia lipolytica strains overexpressing DGA2 in multicopy. Appl. Microbiol. Biotechnol. 99, 8065-8074. https://doi.org/10.1007/s00253-015-6733-8.

Galafassi, S., Cucchetti, D., Pizza, F., Franzosi, G., Bianchi, D., Compagno, C., 2012. Lipid production for second generation biodiesel by the oleaginous yeast Rhodotorula graminis. Bioresour. Technol. 111, 398-403. https://doi.org/10.1016/J.BIORTECH. 2012.02.004.

Giakoumis, E.G., Sarakatsanis, C.K., 2019. A comparative assessment of biodiesel cetane number predictive correlations based on fatty acid composition. Energies 12, 1-30. https://doi.org/10.3390/en12030422.

Gouveia, L., Oliveira, A.C., 2009. Microalgae as a raw material for biofuels production. J. Ind. Microbiol. Biotechnol. 36, 269-274. https://doi.org/10.1007/s10295-0080495-6.

Grand Duchy of Luxembourg, 2015. Report on the Achievements of the Luxembourg Presidency of the Council of the European Union.

Gunstone, F.D., 1967. An Introduction to the Chemistry and Biochemistry of Fatty Acids and Their Glycerides, second ed. Springer US, New York. https://doi.org/10.1021/ ed047pa314.

Gustone, F., 2004. The Chemistry of Oils and Fats: Sources, Composition, Properties and Uses. Willey-Blackwell, Oxford, UK.

Haberkern, B., Maier, W., Schneider, U., 2008. Steigerung Der Energieeffizienz auf Kommunalen Kläranlagen. Umweltbundesamt Texte 11/08. Dessau-Roßlau, Germany.

Hajjari, M., Ardjmand, M., Tabatabaei, M., 2014. Experimental investigation of the effect of cerium oxide nanoparticles as a combustion-improving additive on biodiesel oxidative stability: mechanism. RSC Adv. 4, 14352-14356. https://doi.org/10.1039/ c3ra47033d.

Hall, J., Hetrick, M., French, T., Hernandez, R., Donaldson, J., Mondala, A., Holmes, W., 2011. Oil production by a consortium of oleaginous microorganisms grown on primary effluent wastewater. J. Chem. Technol. Biotechnol. 86, 54-60. https://doi.org/ 10.1002/jctb.2506.

Han, S.F., Jin, W., Tu, R., Abomohra, A.E.F., Wang, Z.H., 2016. Optimization of aeration for biodiesel production by Scenedesmus obliquus grown in municipal wastewater. Bioprocess Biosyst. Eng. 39, 1073-1079. https://doi.org/10.1007/s00449-0161585-x.

Hansen, K., Mulhall, D., Zils, M., Koch, T., Lusceure, L., Saffnauer, S., Braungart, M., 2014. Luxembourg as a knowledge capital and testing ground for the circular economy. National Roadmap to Positive Impacts. Tradition, Transition, Transformation.

Henkel, J., 2010. Oxygen Transfer Phenomena in Activated Sludge. Technical University of Darmstadt.

Hodaifa, G., Sánchez, S., Martínez, M.E., Órpez, R., 2013. Biomass production of Scenedesmus obliquus from mixtures of urban and olive-oil mill wastewaters used as culture medium. Appl. Energy 104, 345-352. https://doi.org/10.1016/j.apenergy. 2012.11.005.

Hu, Q., Sommerfeld, M., Jarvis, E., Ghirardi, M., Posewitz, M., Seibert, M., Darzins, A., 2008. Microalgal triacylglycerols as feedstocks for biofuel production: perspectives and advances. Plant J. 54, 621-639. https://doi.org/10.1111/j.1365-313X.2008. 03492.x.

Huerlimann, R., de Nys, R., Heimann, K., 2010. Growth, lipid content, productivity, and fatty acid composition of tropical microalgae for scale-up production. Biotechnol. Bioeng. 107, 245-257. https://doi.org/10.1002/bit.22809.

Hwu, C.S., Tseng, S.K., Yuan, C.Y., Kulik, Z., Lettinga, G., 1998. Biosorption of long-chain fatty acids in UASB treatment process. Water Res. 32, 1571-1579 10.1016/S00431354(97)00352-7.

Ichihara, K., Fukubayashi, Y., 2010. Preparation of fatty acid methyl esters for gas-liquid chromatography. J. Lipid Res. 51, 635-640. https://doi.org/10.1194/jlr.d001065.

Indarti, E., Majid, M.I.A., Hashim, R., Chong, A., 2005. Direct FAME synthesis for rapid total lipid analysis from fish oil and cod liver oil. J. Food Compos. Anal. 18, 161-170. https://doi.org/10.1016/j.jfca.2003.12.007.

ISTC, 2006. Feasibility Report. Small Scale Biodiesel Production.

Jardé, E., Mansuy, L., Faure, P., 2005. Organic markers in the lipidic fraction of sewage sludges. Water Res. 39, 1215-1232. https://doi.org/10.1016/j.watres.2004.12.024.

Jenicek, P., Bartacek, J., Kutil, J., Zabranska, J., Dohanyos, M., 2012. Potentials and limits of anaerobic digestion of sewage sludge: energy self-sufficient municipal wastewater treatment plant? Water Sci. Technol. 66, 1277-1281. https://doi.org/10. 2166/wst.2012.317.

Kabbe, C., 2015. P-REX Project final report. Sustainable Sewage Sludge Management Forstering Phosphorus Recovery and Energy Efficiency. Berlin.

Kehrein, P., Van Loosdrecht, M., Osseweijer, P., Garfí, M., Dewulf, J., Posada, J., 2020. A critical review of resource recovery from municipal wastewater treatment plantsmarket supply potentials, technologies and bottlenecks. Environ. Sci. Water Res. Technol. 6, 877-910. https://doi.org/10.1039/c9ew00905a.

KPMG, 2014. A New Vision of Value: Connecting Corporate and Societal Value Creation.

Kumar, D., Singh, B., Korstad, J., 2017. Utilization of lignocellulosic biomass by oleaginous yeast and bacteria for production of biodiesel and renewable diesel. Renew. Sustain. Energy Rev. 73, 654-671. https://doi.org/10.1016/j.rser.2017.01.022.

Kumar, M., Thakur, I.S., 2018. Municipal secondary sludge as carbon source for production and characterization of biodiesel from oleaginous bacteria. Bioresour. Technol. Rep. 4, 106-113. https://doi.org/10.1016/j.biteb.2018.09.011.

Lazar, Z., Liu, N., Stephanopoulos, G., 2018. holistic approaches in lipid production by Yarrowia lipolytica. Trends Biotechnol. 36, 1157-1170. https://doi.org/10.1016/j. tibtech.2018.06.007.

Lepage, G., Roy, C.C., 1984. Improved recovery of fatty acid through direct transesterification without prior extraction or purification. J. Lipid Res. 25, 1391-1396.

Li, Q., Du, W., Liu, D., 2008. Perspectives of microbial oils for biodiesel production. Appl. Microbiol. Biotechnol. 80, 749-756. https://doi.org/10.1007/s00253-008-1625-9.

Li, Y., Chen, Y.F., Chen, P., Min, M., Zhou, W., Martinez, B., Zhu, J., Ruan, R., 2011. Characterization of a microalga Chlorella sp. well adapted to highly concentrated municipal wastewater for nutrient removal and biodiesel production. Bioresour. Technol. 102, 5138-5144. https://doi.org/10.1016/j.biortech.2011.01.091.

Li, Y., Han, D., Hu, G., Dauvillee, D., Sommerfeld, M., Ball, S., Hu, Q., 2010. Chlamydomonas starchless mutant defective in ADP-glucose pyrophosphorylase hyper-accumulates triacylglycerol. Metab. Eng. 12, 387-391. https://doi.org/10 1016/j.ymben.2010.02.002.

Liang, M.H., Jiang, J.G., 2013. Advancing oleaginous microorganisms to produce lipid via metabolic engineering technology. Prog. Lipid Res. 52, 395-408. https://doi.org/10. 1016/j.plipres.2013.05.002

Lindtner, S., 2008. Leitfaden Für Die Erstellung Eines Energiekonzeptes Kommunaler Kläranlagen. Wien, Austria.

Ling, J., de Toledo, R.A., Shim, H., 2016. Biodiesel production from wastewater using oleaginous yeast and microalgae. In: Prasad, M.N.V., Shih, K. (Eds.), Environmental Materials and Waste: Resource Recovery and Pollution Prevention. Elsevier, London, pp. 179-212. https://doi.org/10.1016/B978-0-12-803837-6.00008-1.

Liu, L., Hong, Y., Ye, X., Wei, L., Liao, J., Huang, X., Liu, C., 2018. Biodiesel production from microbial granules in sequencing batch reactor. Bioresour. Technol. 249, 908-915. https://doi.org/10.1016/j.biortech.2017.10.105.

Liu, Y., 2003. Chemically reduced excess sludge production in the activated sludge process. Chemosphere 50, 1-7 10.1016/S0045-6535(02)00551-9.

Loehr, R.C., Roth, J.C., 1968. Aerobic degradation of long-chain fatty acid salts. Water Pollut. Control Fed. 40, 385-403.

Lübken, M., Gehring, T., Wichern, M., 2010. Microbiological fermentation of lignocellulosic biomass: current state and prospects of mathematical modeling. Appl. Microbiol. Biotechnol. 85, 1643-1652. https://doi.org/10.1007/s00253-009-2365-1.

Luxembourg, 2013. Governmental Program Grand Duchy of Luxembourg: Legislative Period 2014-2018.

Ma, F., Hanna, M.A., 1999. Biodiesel production: a review. Bioresour. Technol. 70, 1-15.

Ma, H., Addy, M.M., Anderson, E., Liu, W., Liu, Y., Nie, Y., Chen, P., Cheng, B., Lei, H., Ruan, R., 2016. A novel process for low-sulfur biodiesel production from scum waste. Bioresour. Technol. 214, 826-835. https://doi.org/10.1016/j.biortech.2016.05.029.

Mahapatra, D.M., Chanakya, H.N., Ramachandra, T.V., 2014. Bioremediation and lipid synthesis through mixotrophic algal consortia in municipal wastewater. Bioresour. Technol. 168, 142-150. https://doi.org/10.1016/j.biortech.2014.03.130.

Mahlie, W.S., 1940. Oil and grease in sewage. Sewage Work. J. 12, 527-556.

Mata, T.M., Martins, A.A., Caetano, N.S., 2010. Microalgae for biodiesel production and other applications: a review. Renew. Sustain. Energy Rev. 14, 217-232. https://doi. org/10.1016/j.rser.2009.07.020.

Menegazzo, M.L., Fonseca, G.G., 2019. Biomass recovery and lipid extraction processes for microalgae biofuels production: a review. Renew. Sustain. Energy Rev. 107, 87-107. https://doi.org/10.1016/j.rser.2019.01.064.

Meng, X., Yang, J., Xu, X., Zhang, L., Nie, Q., Xian, M., 2009. Biodiesel production from oleaginous microorganisms. Renew. Energy 34, 1-5. https://doi.org/10.1016/j. renene. 2008.04.014.

Miranda, A.F., Ramkumar, N., Andriotis, C., Höltkemeier, T., Yasmin, A., Rochfort, S., Wlodkowic, D., Morrison, P., Roddick, F., Spangenberg, G., Lal, B., Subudhi, S., Mouradov, A., 2017. Applications of microalgal biofilms for wastewater treatment 
and bioenergy production. Biotechnol. Biofuels 10, 1-23. https://doi.org/10.1186/ s13068-017-0798-9.

Molina Grima, E., Belarbi, E.H., Acién Fernández, F.G., Robles Medina, A., Chisti, Y. 2003. Recovery of microalgal biomass and metabolites: process options and economics. Biotechnol. Adv. 20, 491-515 10.1016/S0734-9750(02)00050-2.

Mondala, A., Liang, K., Toghiani, H., Hernandez, R., French, T., 2009. Biodiesel production by in situ transesterification of municipal primary and secondary sludges. Bioresour. Technol. 100, 1203-1210. https://doi.org/10.1016/J.BIORTECH.2008. 08.020.

Muniraj, I.K., Uthandi, S.K., Hu, Z., Xiao, L., Zhan, X., 2015. Microbial lipid production from renewable and waste materials for second-generation biodiesel feedstock. Environ. Technol. Rev. 4, 1-16. https://doi.org/10.1080/21622515.2015.1018340.

Mutanda, T., Karthikeyan, S., Bux, F., 2011. The utilization of post-chlorinated municipal domestic wastewater for biomass and lipid production by Chlorella spp. under batch conditions. Appl. Biochem. Biotechnol. 164, 1126-1138. https://doi.org/10.1007/ s12010-011-9199-x.

Nguyen Doan, H.T., 2019. Le train de l'economie circulaire est en marche. Bull. Econ. la Chamb. Commer. Actual. Tend. 60.

Niehaus, R.A., Goering, C.A., Savage, L.D.,J., Sorenson, S.C., 2013. Cracked soybean oil as a fuel for a diesel engine. Trans. ASAE 29, 683-689. https://doi.org/10.13031/2013. 30213.

OECD, 2019. The Circular Economy in Cities and Regions.

Olguín, E.J., Olguin Eugenia, J., 2012. Dual purpose microalgae-bacteria-based systems that treat wastewater and produce biodiesel and chemical products within a Biorefinery. Biotechnol. Adv. 30, 1031-1046. https://doi.org/10.1016/j.biotechadv 2012.05.001.

Olkiewicz, M., Caporgno, M.P., Fortuny, A., Stüber, F., Fabregat, A., Font, J., Bengoa, C., 2014. Direct liquid-liquid extraction of lipid from municipal sewage sludge for biodiesel production. Fuel Process. Technol. 128, 331-338. https://doi.org/10.1016/j fuproc.2014.07.041.

Olkiewicz, M., Fortuny, A., Stüber, F., Fabregat, A., Font, J., Bengoa, C., 2012. Evaluation of different sludges from WWTP as a potential source for biodiesel production. Procedia Eng. 42, 634-643. https://doi.org/10.1016/j.proeng.2012.07.456.

Olkiewicz, M., Fortuny, A., Stüber, F., Fabregat, A., Font, J., Bengoa, C., 2015. Effects of pre-treatments on the lipid extraction and biodiesel production from municipal WWTP sludge. Fuel 141, 250-257. https://doi.org/10.1016/j.fuel.2014.10.066.

Ötleş, S., Pire, R., 2001. Fatty acid composition of Chlorella and Spirulina microalgae species. J. AOAC Int. 84, 1708-1714.

Park, S.J., Choi, Y.E., Kim, E.J., Park, W.K., Kim, C.W., Yang, J.W., 2011. Serial optimization of biomass production using microalga Nannochloris oculata and corresponding lipid biosynthesis. Bioprocess Biosyst. Eng. 35, 3-9. https://doi.org/10. 1007/s00449-011-0639-3.

Pastore, C., Lopez, A., Lotito, V., Mascolo, G., 2013. Biodiesel from dewatered wastewater sludge: a two-step process for a more advantageous production. Chemosphere 92 , 667-673. https://doi.org/10.1016/j.chemosphere.2013.03.046.

Pastore, C., Lopez, A., Mascolo, G., 2014. Efficient conversion of brown grease produced by municipal wastewater treatment plant into biofuel using aluminium chloride hexahydrate under very mild conditions. Bioresour. Technol. 155, 91-97. https://doi. org/10.1016/j.biortech.2013.12.106.

Pastore, C., Pagano, M., Lopez, A., Mininni, G., Mascolo, G., 2015. Fat, oil and grease waste from municipal wastewater: characterization, activation and sustainable conversion into biofuel. Water Sci. Technol. 71, 1151-1157. https://doi.org/10.2166/ wst.2015.084.

Patiño, Y., Mantecón, L.G., Polo, S., Faba, L., Díaz, E., Ordóñez, S., 2018. Effect of sludge features and extraction-esterification technology on the synthesis of biodiesel from secondary wastewater treatment sludges. Bioresour. Technol. 247, 209-216. https:// doi.org/10.1016/j.biortech.2017.09.058.

Penn, R., Ward, B.J., Strande, L., Maurer, M., 2018. Review of synthetic human faeces and faecal sludge for sanitation and wastewater research. Water Res. 132, 222-240. https://doi.org/10.1016/j.watres.2017.12.063.

Peterson, C.L., Auld, D.L., Korus, R.A., 1983. Winter rape oil fuel for diesel engines: recovery and utilization. J. Am. Oil Chem. Soc. 60, 1579-1587. https://doi.org/10. 1007/BF02666589.

Pioch, D., Loanzo, P., Rasoanantoandro, M.C., Graille, J., Geneste, P., Guida, A., 1993. Biofuels from catalytic cracking of tropical vegetable oils. Oléagineux 48, 289-291.

Piras, A., Rosa, A., Marongiu, B., Porcedda, S., Falconieri, D., Dessì, M.A., Ozcelik, B., Koca, U., 2013. Chemical composition and in vitro bioactivity of the volatile and fixed oils of Nigella sativa L. extracted by supercritical carbon dioxide. Ind. Crops Prod. 46, 317-323. https://doi.org/10.1016/j.indcrop.2013.02.013.

Pratoomyot, J., Srivilas, P., Noiraksar, T., 2005. Fatty acids composition of 10 microalgal species. Songklanakarin J. Sci. Technol. 27, 1179-1187.

Qin, L., Liu, L., Zeng, A.P., Wei, D., 2017. From low-cost substrates to Single Cell Oils synthesized by oleaginous yeasts. Bioresour. Technol. 245, 1507-1519. https://doi org/10.1016/j.biortech.2017.05.163.

Quéméneur, M., Marty, Y., 1994. Fatty acids and sterols in domestic wastewaters. Water Res. 28, 1217-1226 10.1016/0043-1354(94)90210-0.

Raunkjær, K., Hvitved-Jacobsen, T., Nielsen, P.H., 1994. Measurement of pools of protein, carbohydrate and lipid in domestic wastewater. Water Res. 28, 251-262 10.1016/ 0043-1354(94)90261-5.

Revellame, E., Hernandez, R., French, W., Holmes, W., Alley, E., 2010. Biodiesel from activated sludge through in situ transesterification. J. Chem. Technol. Biotechnol. 85, 614-620. https://doi.org/10.1002/jctb. 2317.

Rombaut, N., Tixier, A.S., Bily, A., Chemat, F., 2014. Green extraction processes of natural products as tools for biorefinery. Biofuels Bioprod. Biorefin. 8, 530-544. https://doi. org/10.1002/bbb.1486.

Rossi, M., Amaretti, A., Raimondi, S., Leonardi, A., 2011. Getting lipids for biodiesel production from oleaginous fungi. In: Stoytcheva, M., Montero, G (Eds.), Biodiesel Feedstocks and Processing Technologies. InTech, Rijeka, Croatia, pp. 71-92. https:// doi.org/10.5772/25864.

Ryu, B.G., Kim, E.J., Kim, H.S., Kim, J., Choi, Y.E., Yang, J.W., Byung-Gon, R., Eun Jung, K., Hee-Sik, K., Jungmin, K., Yoon, E.C., Ji-Won, Y., 2014. Simultaneous treatment of municipal wastewater and biodiesel production by cultivation of Chlorella vulgaris with indigenous wastewater bacteria. Biotechnol. Bioprocess Eng. 19, 201-210. https://doi.org/10.1007/s12257-013-0250-3.

Sacristán de Alva, M., Luna-Pabello, V.M., Cadena, E., Ortíz, E., 2013. Green microalga Scenedesmus acutus grown on municipal wastewater to couple nutrient removal with lipid accumulation for biodiesel production. Bioresour. Technol 146, 744-748. https://doi.org/10.1016/j.biortech.2013.07.061.

Sagnak, R., Cochot, S., Molina-Jouve, C., Nicaud, J.M., Guillouet, S.E., 2018. Modulation of the Glycerol Phosphate availability led to concomitant reduction in the citric acid excretion and increase in lipid content and yield in Yarrowia lipolytica. J. Biotechnol. 265, 40-45. https://doi.org/10.1016/j.jbiotec.2017.11.001.

Samios, D., Pedrotti, F., Nicolau, A., Reiznautt, Q.B., Martini, D.D., Dalcin, F.M., 2009. A transesterification double step process - TDSP for biodiesel preparation from fatty acids triglycerides. Fuel Process. Technol. 90, 599-605. https://doi.org/10.1016/j. fuproc.2008.12.011.

Sangaletti-Gerhard, N., Cea, M., Risco, V., Navia, R., 2015. In situ biodiesel production from greasy sewage sludge using acid and enzymatic catalysts. Bioresour. Technol. 179, 63-70. https://doi.org/10.1016/J.BIORTECH.2014.12.003.

Schmitt, N., Apfelbacher, A., Jäger, N., Daschner, R., Stenzel, F., Hornung, A., 2019. Thermo-chemical conversion of biomass and upgrading to biofuel: the thermo-catalytic reforming process - a review. Biofuels Bioprod. Biorefin. 1-16. https://doi.org/ $10.1002 / \mathrm{bbb}$

Schwab, A.W., Bagby, M.O., Freedman, B., 1987. Preparation and properties of diesel fuels from vegetable oils. Fuel 66, 1372-1378 10.1016/0016-2361(87)90184-0.

Segura, R., 1988. Preparation of fatty acid methyl esters by direct transesterification of lipids with aluminium chloride-methanol. J. Chromatogr. A 441, 99-113 10.1016/ S0021-9673(01)84658-6.

Selvakumar, P., Sivashanmugam, P., 2019. Ultrasound assisted oleaginous yeast lipid extraction and garbage lipase catalyzed transesterification for enhanced biodiesel production. Energy Convers. Manag. 179, 141-151. https://doi.org/10.1016/j. enconman.2018.10.051.

SeRaMCo, 2019. Secondary raw materials for concrete precast products [WWW Document]. Interreg North-West Eur URL. http://www.nweurope.eu/projects/ project-search/seramco-secondary-raw-materials-for-concrete-precast-products/\# tab-1 (accessed 10.7.19).

Sergeeva, Y.E., Galanina, L.A., Andrianova, D.A., Feofilova, E.P., 2008. Lipids of filamentous fungi as a material for producing biodiesel fuel. Appl. Biochem. Microbiol. 44, 523-527. https://doi.org/10.1134/S0003683808050128.

SevernTrent, 2016.

Sheng, J., Vannela, R., Rittmann, B.E., 2012. Disruption of Synechocystis PCC 6803 for lipid extraction. Water Sci. Technol. 65, 567-573. https://doi.org/10.2166/wst. 2012.879.

Siddiquee, M.N., Rohani, S., 2011. Experimental analysis of lipid extraction and biodiesel production from wastewater sludge. Fuel Process. Technol. https://doi.org/10.1016/ j.fuproc.2011.07.018.

SMDR, 2013. Spinning Mesh Disc Reactors: A New Paradigm for Photocatalytic and Enzymatic Reaction Intensification [WWW Document]. URL. https://cordis.europa. eu/project/rcn/108122/factsheet/en (accessed 10.3.19).

Soddell, J.A., Seviour, R.J., Blackall, L.L., Hugenholtz, P., 1998. New foam-forming nocardioforms found in activated sludge. Water Sci. Technol. 37, 495-502 10.1016/ S0273-1223(98)00151-6.

SOLENALGAE, 2016. Improving Photosynthetic Solar Energy Conversion in Microalgal Cultures for the Production of Biofuels and High Value Products [WWW Document]. URL https://www.solelab.org/solenalgae (accessed 10.10.19).

Strayer, R.C., Blake, J.A., Craig, W.K., 1983. Canola and high erucic rapeseed oil as substitutes for diesel fuel: preliminary tests. J. Am. Oil Chem. Soc. 60, 1587-1592. https://doi.org/10.1007/BF02666590.

Sutton, M.A., van Grinsven, H., Billen, G., Bleeker, A., Bouwman, A.F., Bull, K., Erisman, J.W., Grennfelt, P., Grizzetti, B., Howard, C.M., Oenema, O., Spranger, T., Winiwarter, W., 2011. Summary for policy makers. In: Sutton, M.A., Howard, C.M., Erisman, J.W., Billen, G., Bleeker, A., Grennfelt, P., van Grinsven, H., Grizzetti, B. (Eds.), The European Nitrogen Assessment. Cambridge University Press, New York, pp. xxiv-xxxiv. https://doi.org/10.1017/CBO9780511976988.002.

Tai, M., Stephanopoulos, G., 2013. Engineering the push and pull of lipid biosynthesis in oleaginous yeast Yarrowia lipolytica for biofuel production. Metab. Eng. 15, 1-9. https://doi.org/10.1016/j.ymben.2012.08.007.

Temelli, F., 2009. Perspectives on supercritical fluid processing of fats and oils. J. Supercrit. Fluids 47, 583-590. https://doi.org/10.1016/j.supflu.2008.10.014.

Thakur, M.S., Prapulla, S.G., Karanth, N.G., 1988. Microscopic observation of Sudan Black B staining to monitor lipid production by microbes. J. Chem. Technol. Biotechnol. 42, 129-134. https://doi.org/10.1002/jctb.280420206.

Thomas, W.H., Tornabene, T.G., Weissman, J., 1984. Screening for Lipid Yielding Microalgae: Activities for 1983. SERI/STR-231-2207, Golden, USA. https://doi.org/ 10.2172/6838870.

TO-SYN-FUEL, 2017. The Demonstration of Waste Biomass to Synthetic Fuels and Green Hydrogen [WWW Document]. URL http://www.tosynfuel.eu/ (accessed 12.3.19).

Turovskiy, I.S., Mathai, P.K., 2006. Chapter 2: Sludge quantities and characteristics. Wastewater Sludge Processing. Wiley-Interscience, Hoboken, New Jersey, pp. 30-59.

Usewaste, 2018. Patented Modified-Immobilized Enzymes used in the Production of Biodiesel at Commercial Scales using any Type of Feedstock [WWW Document]. URL https://cordis.europa.eu/project/rcn/216864/factsheet/en (accessed 10.13.19). 
Van Den Hende, S., Vervaeren, H., Desmet, S., Boon, N., 2011. Bioflocculation of microalgae and bacteria combined with flue gas to improve sewage treatment. N. Biotechnol 29, 23-31. https://doi.org/10.1016/j.nbt.2011.04.009.

Van Gerpen, J., 2005. Biodiesel processing and production. Fuel Process. Technol. 86, 1097-1107. https://doi.org/10.1016/j.fuproc.2004.11.005.

Vasiliadou, I.A., Sánchez-Vázquez, R., Molina, R., Martínez, F., Melero, J.A., Bautista, L.F., Iglesias, J., Morales, G., 2016. Biological removal of pharmaceutical compounds using white-rot fungi with concomitant FAME production of the residual biomass. J. Environ. Manag. 180, 228-237. https://doi.org/10.1016/j.jenvman.2016.05.035.

Vicente, G., Bautista, L.F., Rodríguez, R., Gutiérrez, F.J., Sádaba, I., Ruiz-Vázquez, R.M., Torres-Martínez, S., Garre, V., 2009. Biodiesel production from biomass of an oleaginous fungus. Biochem. Eng. J. 48, 22-27. https://doi.org/10.1016/j.bej.2009.07. 014.

VSA - Verband Schweizer Abwasserund Gewässerschutzfachleute, 2010. Energie in ARA, leitfaden zur energieoptimierung AUF abwasserreinigungsanlagen. Handbuch Im Auftrag Des Bundesamtes Für Energie Und Des VSA, Bern, Switzerland.

Wang, C., Chen, L., Rakesh, B., Qin, Y., Lv, R., 2012. Technologies for extracting lipids from oleaginous microorganisms for biodiesel production. Front. Energy 6, 266-274. https://doi.org/10.1007/s11708-012-0193-y.

Wang, L., Min, M., Li, Y., Chen, P., Chen, Y., Liu, Y., Wang, Y., Ruan, R., 2010. Cultivation of green algae Chlorella sp. in different wastewaters from municipal wastewater treatment plant. Appl. Biochem. Biotechnol. 162, 1174-1186. https://doi.org/10 1007/s12010-009-8866-7.

Wang, Y., Feng, S., Bai, X., Zhao, J., Xia, S., 2016. Scum sludge as a potential feedstock for biodiesel production from wastewater treatment plants. Waste Manag. 47, 91-97. https://doi.org/10.1016/j.wasman.2015.06.036.

Wang, Z.P., Xu, H.M., Wang, G.Y., Chi, Z., Chi, Z.M., 2013. Disruption of the MIG1 gene enhances lipid biosynthesis in the oleaginous yeast Yarrowia lipolytica ACA-DC 50109. Biochim. Biophys. Acta 1831, 675-682. https://doi.org/10.1016/j.bbalip. 2012.12.010.
Watecco, 2014. Water Column Profiler for Quantification of Photosynthesis and Biomass of Phytoplankton in Natural and Man Made Water Bodies [WWW Document]. URL https://cordis.europa.eu/project/rcn/193645/factsheet/en (accessed 10.13.19).

Weisz, P.B., Haag, W.O., Rodewald, P.G., 1979. Catalytic production of high-grade fuel (gasoline) from biomass compounds by shape-selective catalysis. Science 206, 57-58. https://doi.org/10.1126/science.206.4414.57.

Williams, J.A., Sharma, A., Morris, L.J., Holman, R.T., 1960. Fatty acid composition of feces and fecaliths. Proc. Soc. Exp. Biol. Med. 105, 192-195. https://doi.org/10. 3181/00379727-105-26052.

Williams, J.B., Clarkson, C., Mant, C., Drinkwater, A., May, E., 2012. Fat, oil and grease deposits in sewers: characterisation of deposits and formation mechanisms. Water Res. 46, 6319-6328. https://doi.org/10.1016/j.watres.2012.09.002.

Woertz, I., Feffer, A., Lundquist, T., Nelson, Y., 2009. Algae grown on dairy and municipal wastewater for simultaneous nutrient removal and lipid production for biofuel feedstock. J. Environ. Eng. 1, 1115-1122 10.1061/(asce)ee.1943-7870.0000129.

WOW!, 2018. Wider Business Opportunities for Raw Materials from Wastewater [WWW Document]. URL http://www.nweurope.eu/projects/project-search/wow-widerbusiness-opportunities-for-raw-materials-from-wastewater/ (accessed 10.7.19).

Wright, H.J., Segur, J.B., Clark, H.V., Coburn, S.K., Langdon, E.E., DuPuis, R.N., 1944. A report on ester interchange. Oil Soap 21, 145-148. https://doi.org/10.1007/ BF02549470.

Zhang, X., Yan, S., Tyagi, R.D., Surampalli, R.Y., Valéro, J.R., 2014. Wastewater sludge as raw material for microbial oils production. Appl. Energy 135, 192-201. https://doi. org/10.1016/j.apenergy.2014.08.078.

Zhao, Q., Kugel, G., 1996. Thermophilic/mesophilic digestion of sewage sludge and organic wastes. J. Environ. Sci. Heal. 31, 2211-2231.

Zhou, W., Min, M., Li, Y., Hu, B., Ma, X., Cheng, Y., Liu, Y., Chen, P., Ruan, R., 2012. A hetero-photoautotrophic two-stage cultivation process to improve wastewater nutrient removal and enhance algal lipid accumulation. Bioresour. Technol. 110, 448-455. https://doi.org/10.1016/j.biortech.2012.01.063. 